\title{
Enhancement of Permeability Activated by Supercritical Fluid Flow through Granite
}

\author{
Tsuyoshi Nohara $\left(\mathbb{D},{ }^{1}\right.$ Masaoki Uno $\mathbb{D}^{2},{ }^{2}$ and Noriyoshi Tsuchiya ${ }^{2}$ \\ ${ }^{1}$ Geoscientific Research Department, Tono Geoscience Center, Sector of Nuclear Fuel, Decommissioning and Waste Management \\ Technology Development, Japan Atomic Energy Agency, Yamanouchi, 1-64, Akiyo-cho, Mizunami, Gifu 509-6132, Japan \\ ${ }^{2}$ Graduate School of Environmental Studies, Tohoku University, Aramaki-aza-Aoba, 6-6-20, Aoba-ku, Sendai 980-8579, Japan
}

Correspondence should be addressed to Tsuyoshi Nohara; nohara.tsuyoshi@jaea.go.jp

Received 7 March 2019; Revised 28 May 2019; Accepted 19 June 2019; Published 4 August 2019

Guest Editor: Roman Makhnenko

Copyright (c) 2019 Tsuyoshi Nohara et al. This is an open access article distributed under the Creative Commons Attribution License, which permits unrestricted use, distribution, and reproduction in any medium, provided the original work is properly cited.

\begin{abstract}
This geological study utilized electron probe microanalysis of granitic rocks to evaluate traces of hydrothermal fluid activity. Amphibole-plagioclase thermometry was applied to estimate the temperature of a glassy vein as approximately $700^{\circ} \mathrm{C}$. The results of mesoscopic and microscopic observations of the rock core obtained through borehole investigations revealed that the track of supercritical fluid flow was microfracture filling with hornblende and plagioclase. Grain-boundary microfractures and parallel microfractures were recognized as traces formed by the limited activity of the supercritical fluid immediately after granite setting in the Late Cretaceous. The current high permeability of a borehole in and around the track of supercritical fluid flow was recognized to be related to the microfracture network. In order to investigate the enhancement of permeability activated by the supercritical fluid flow through granite, the results of this geological study and existing data from in situ permeability tests were analysed. Various fractures in and around the trace of a self-sealing zone were investigated for another borehole rock core. The trace of the self-sealing zone, which was composed of filling textures associated with the supercritical fluid, corresponded to the current low-permeability section of the borehole. Representative types were proposed for simple classification based on the characteristics of fractures and the permeability data of each test section. A high-angle fracture of chlorite filling in combination with an open fracture and the development of a sericite-filling fracture network including a lowangle open fracture were recognized as characteristics of high-permeability types. The results of this study indicate that the enhancement of permeability was activated by supercritical fluid flow through granite.
\end{abstract}

\section{Introduction}

Granitic rock masses in a mobile belt often contain welldeveloped fractures and display a wide range of permeability values [1-3]. Understanding the mechanisms that cause the formation of these continuous fractures is important for both geothermal energy development and the geological disposal of high-level radioactive waste. Fault movement has long been considered as the primary cause of fracture formation [4]. More recently, fracture formation in granite has been attributed to causes other than fault movement, including the thermal stress that accompanies heating [5], the contrac- tion that accompanies cooling [6,7], and the stress relief associated with erosion forces [8].

A significant body of research has employed field surveys and laboratory analyses to evaluate the effects of fault movement and thermal stress on the fracture formation process. In a field study related to fault movement, microfracture formation in granite was found to be limited to feldspar grains during the initial stages of movement [9]. This was confirmed in the laboratory, where initial microfractures developed primarily in the feldspar grains during the load testing of granite specimens $[10,11]$. In contrast, subsequent heating and cooling experiments have indicated that microfractures can also 
form along the crystal grain boundary under thermal-stress conditions that are created when the temperature exceeds the $\alpha-\beta$ phase-transition temperature of quartz [5].

Laboratory testing on the generation of shear displacement with in-cut granite surfaces, which was used to investigate changes in permeability due to faulting, showed an increase in the permeability coefficient by 1-2 orders of magnitude [12]. Regarding thermal cracking, when cylindrical specimens of intact granite were heated to $700^{\circ} \mathrm{C}$, the permeability $\left(\mathrm{m}^{2}\right)$ assessed after cooling was increased by $4-5$ orders of magnitude [13]. Watanabe et al. [14] found that permeability behaviour for fractured granite samples at $350-500^{\circ} \mathrm{C}$ under effective confining stress was characterized by a transition from a weakly stress-dependent and reversible behaviour to a strongly stress-dependent and irreversible behaviour at a specific, temperature-dependent effective confining stress level. This transition was induced by onset of plastic normal deformation of the fracture surface (elasticplastic transition) and, importantly, causes no "jump" in the permeability [14].

Some permeability depth relations proposed for the continental crust show no drastic permeability reduction at the brittle-ductile transition [15]. Increases in fluid pressure and temperature within the brittle domain lead to faulting and brecciation, which increase permeability and allow an increase in the rate of discharge of hydrothermal fluids [16]. In natural analogue research of geothermal areas in Japan, the characteristics of fractures and fillings related to high-temperature fluids have been studied [17] but research on the fracturing associated with supercritical fluids in nongeothermal fields has yet to be conducted.

The Toki granite of central Japan, which has been the subject of geoscientific studies pertaining to high-level radioactive waste disposal, provides an opportunity for such research. The Toki granite was more extensively investigated in terms of fracture distribution. In this area, numerous borehole investigations were conducted, and the results of in situ permeability tests were reported [18]. Accordingly, in the present study, a geological investigation on the Toki granite was conducted to better understand the distribution of fractures accompanying the flow of supercritical fluids, and amphibole-plagioclase thermometry was applied to estimate the temperature condition. Furthermore, a relationship between the distributions of fractures related to supercritical fluid flow and those of heterogeneous permeability was considered based on our investigation data of the rock core and existing in situ permeability test data acquired through borehole surveys. The present study focused on attaining a comprehensive understanding of mineralogical phenomena related to supercritical fluids and on elucidating the relationship between geothermal fracturing and the enhancement of permeability in granite, rather than strictly identifying the geothermal event.

\section{Materials and Methods}

Granite rock masses, which are primarily composed of biotite granite, were observed around Toki City and Mizunami City [19]. Figure 1 shows a geological map depicting the area in and around the Toki granite. The Cretaceous plutonic rocks in the inner zone of southwest Japan were divided into the Ryoke granitoids and Sanyo granitoids. The Toki granite belongs to the latter group [20], while the Inagawa granite belongs to the former group [21]. The Ryoke granitoids are closely associated with the Ryoke metamorphic complex (Cretaceous) [21]. The metamorphic temperature and pressure conditions were estimated as $T=506-593^{\circ} \mathrm{C}$ and $P=$ $2.9-3.7 \mathrm{kbar}$, respectively [22]. In addition, the emplacement pressure condition of the granitic body (Mitsuhashi granodiorite) was estimated to be $4 \mathrm{kbar}$ [23]. The Nohi Rhyolite is one of the largest Late Cretaceous ash-flow fields in central Japan. The Nohi Rhyolite has similar general petrological properties to the hypabyssal granitoid porphyries and granitoids including the Toki granite, which is high-K, I-type, ilmenite-series dacitic to rhyolitic in composition [24]. Such a series of magmatic activities in the upper crust of a mobile belt might have left a trace of the supercritical fluid. On the west side and north side of the Toki granite, a sedimentary complex in the Mino terrane was identified, with a portion being affected by contact metamorphism [25]. The Mino terrane was formed by the subduction of an oceanic plate during the Early Jurassic to earliest Cretaceous time along the eastern margin of the Asian continent [26].

The lithofacies of the Toki granite are classified as fine- to coarse-grained biotite granite and porphyritic biotite granite, and they have a composition that incorporates ilmenite as a major opaque mineral in medium- to coarsegrained biotite granite [19]. The change in lithologic character was long assumed to be associated with contamination of the crust, but the simultaneous intrusion of different magmas could not be contradicted by the presence of a zoned pluton [27].

Most of the Toki granite is covered with post-Tertiary sedimentary rocks and cannot be observed on the surface. This study investigates the distribution of granite and intrusive rock based on data from 73 boreholes obtained in previous drilling surveys. The distribution of basement rocks, such as granite and intrusive rocks, is investigated based on the examination of these data and rock cores (Figure 1). A number of intrusive dikes composed of basaltic to andesitic rocks were identified $[28,29]$. In addition to their alignment characteristics, the dikes display near-vertical dips and are several tens of meters thick, with a parallel distribution at intervals of several hundred meters [30-32].

There is no evidence for recent geothermal activity in the Toki granite. However, epithermal alteration accompanying the significant leaching and the recrystallization that occurred during the Late Cretaceous has been documented [33]. Nishimoto et al. [33] investigated the Rb-Sr isotopic ages of primary and secondary minerals by using the rock cores displaying the most significant leaching. They estimated the $\mathrm{Rb}-\mathrm{Sr}$ isotopic age of the primary and secondary minerals as $76.3 \pm 1.5 \mathrm{Ma}$ and $70.6 \pm 3.1 \mathrm{Ma}$, respectively. It was assumed that these chronological ages are significantly different, with formation occurring in two stages. The first stage is the setting and cooling stage of the Toki granite body, while the porosity generated by the leaching and 


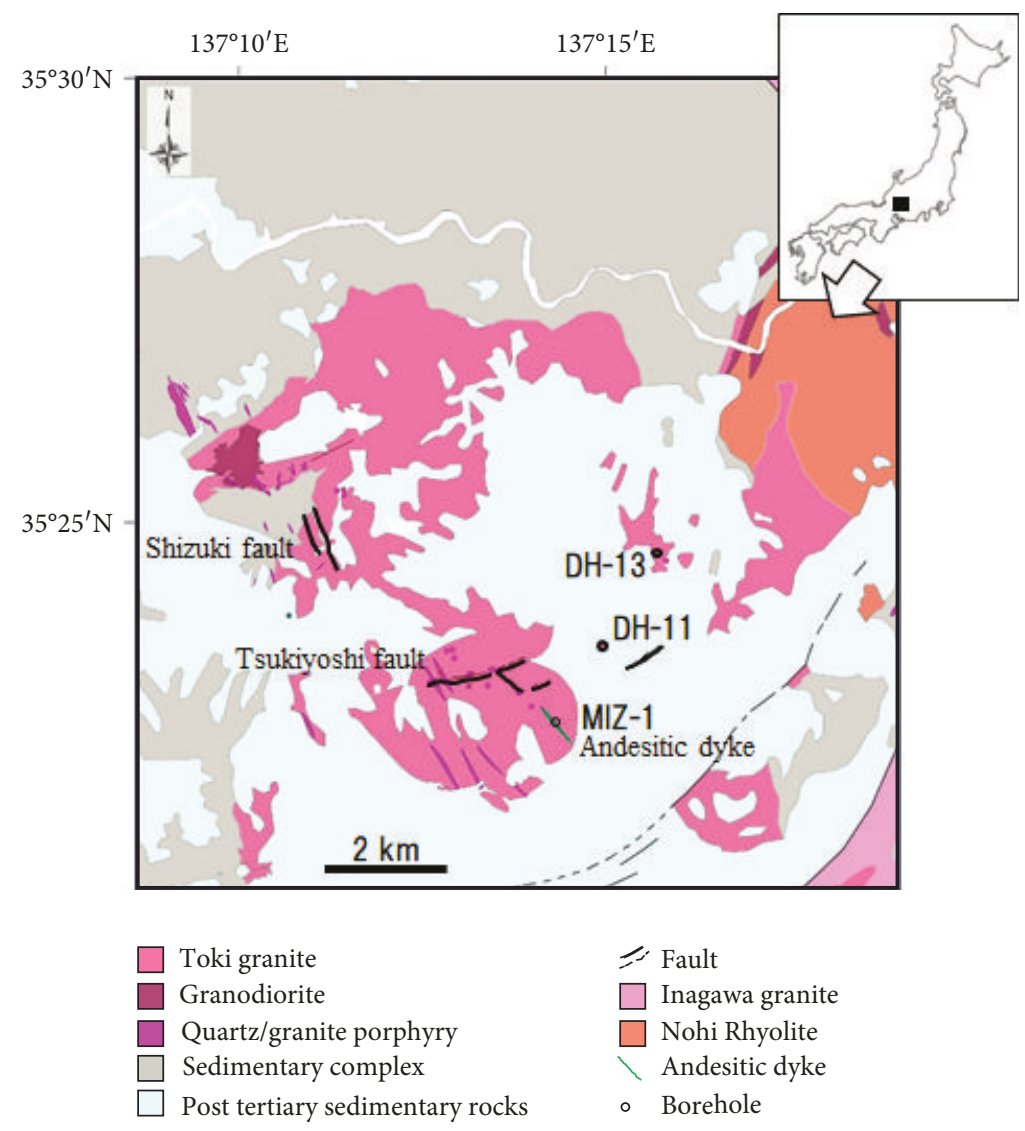

FIgURE 1: Geological map in and around the Toki granite. Distribution of the Toki granite, dike, and surrounding rocks. Based on data from existing boring surveys, some distributions of granites and intrusive rocks covered with post-Tertiary sedimentary rocks are shown.

partial filling with quartz and euhedral chlorite occurred in the second stage. Fluids responsible for the quartz dissolution are little known.

Hydrothermal chloritization of biotite during the subsolidus cooling of the Toki granitic pluton has been reported [34]. Mineralogical effects of hydrothermal alteration, such as partial dissolution of plagioclase, biotite dissolution, and illite precipitation, were also investigated. Hydrothermal alteration of the granite proceeded mainly by a dissolutionprecipitation process resulting from the infiltration of hydrothermal fluid along microcracks [35].

Fault distribution was estimated using the data collected from the boreholes in this area. The Tsukiyoshi fault is a reverse fault with Miocene displacement at several tens of meters [36]. The Shizuki fault is composed of parallel faults with nearly vertical dips running north-northwest to southsoutheast on both sides of the outer rock mass, which were approximately $50 \mathrm{~m}$ lower than the inner rock mass sandwiched between the faults [32]. There is no distribution of a shear zone that caused melting.

Numerous $1000 \mathrm{~m}$ class borehole investigations have been conducted, and the results of in situ permeability tests have been reported [18]. A sequence of in situ permeability tests (pumping, slug, and pulse tests could be selected based on the conditions of each section) was performed by the Japan Atomic Energy Agency (JAEA) by using special hydrogeological test equipment, which consists of a downhole unit suspended from stainless-steel rods and surface equipment with cable reels [1]. The downhole unit consists of five packers and a measurement unit. Therefore, we selected three representative boreholes-DH-11 (1000 m vertical hole), DH-13 (1000 m vertical hole), and MIZ-1 (1200 m controlled hole with a vertical depth up to approximately $500 \mathrm{~m}$ and deeper oblique holes)-based on the results of permeability tests. Generally, materials with a relatively small permeability coefficient of close to $10^{-9} \mathrm{~m} / \mathrm{s}$ are characterized as low-water-permeability materials [37]. The DH-13 borehole had a relatively high permeability (permeability coefficient of 11 test sections: $10^{-6}$ to $10^{-8} \mathrm{~m} / \mathrm{s}$ ), and the DH-11 borehole had a relatively low permeability (permeability coefficient of 10 test sections: $10^{-8}$ to $10^{-10} \mathrm{~m} / \mathrm{s}$ ). The MIZ-1 borehole had the broadest permeability range (permeability coefficient of 20 test sections: $10^{-3}$ to $10^{-11} \mathrm{~m} / \mathrm{s}$ ). For each borehole with different permeability values, fracture characteristics and the filling minerals' formation conditions were investigated in this study.

\section{Results and Discussion}

3.1. Mesoscopic Observation. Mesoscopic observations of the rock cores of the DH-11, DH-13, and MIZ-1 boreholes were performed. Pegmatite, aplite, and andesitic inclusions having diameters on the order of several centimetres were observed in all boreholes. Intrusive rocks of quartz monzonite were 


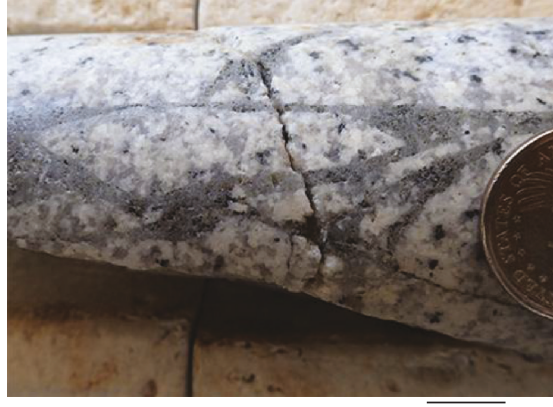

$1 \mathrm{~cm}$

(a)

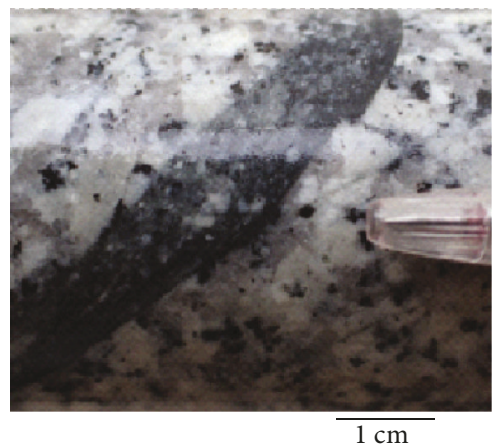

(c)

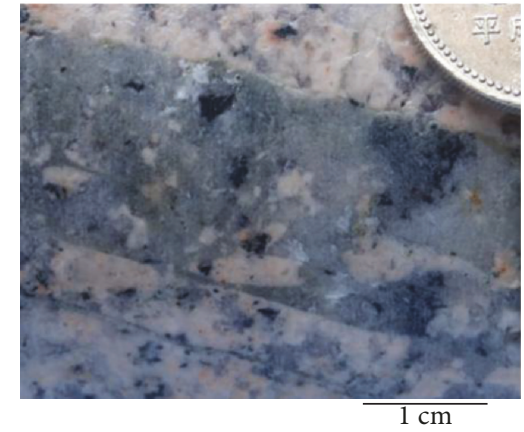

(b)

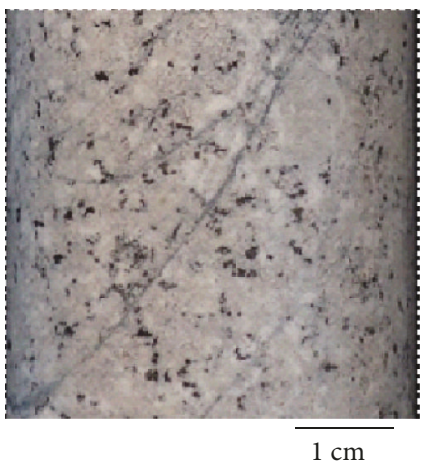

(d)

FIGURE 2: Photographs of rock core samples showing hydrothermal breccia veins in (a) borehole DH-11 and (b) borehole MIZ-1, as well as (c, d) glassy veins in borehole $\mathrm{DH}-13$.

observed in the DH-13 borehole (at depths of approximately $175 \mathrm{~m}$ and approximately $310-330 \mathrm{~m}$ ), and andesitic rocks were observed in the MIZ-1 borehole. Since the hydrothermal alteration is observed near the boundary between intrusive rock and granite, the direction of this boundary cannot be recognized. No intrusive rock is observed in the DH-11 borehole. Mineral filling veins are classified on the basis of the definition of Tsuchiya et al. [17]. Hydrothermal breccia veins in the weak altered host rock were observed in the DH-11 and MIZ-1 boreholes. The hydrothermal breccia vein at a depth of $720-750 \mathrm{~m}$ in the DH-11 borehole contains rubble of the host rock surrounded by quartz fillings (Figure 2(a)). The hydrothermal breccia vein in the MIZ-1 borehole was found at a depth of $980 \mathrm{~m}$ and could be characterized as a quartz vein with brecciated material and small fragments of the host rock (Figure 2(b)). Dips of both of these hydrothermal breccia veins were nearly vertical. Glassy veins (a dark-coloured fine-grained vein composed of quartz, plagioclase, K-feldspar, \pm amphibole, biotite, and chlorite; the predominance of fine-grained quartz gives a "glassy" appearance) were observed in all three boreholes. It exhibits a fine-grained equigranular filling suggestive of melt crystallization. These characteristics are similar to the veins reported by Tsuchiya et al. [17] for the Neogene granitoids in NE Japan. Most glassy veins have a dark-green colour (Figure 2(c)), and all glassy veins in the DH-11 and MIZ-1 boreholes have this colour. Two black glassy veins were observed near depths of $60 \mathrm{~m}$ and $550 \mathrm{~m}$ in the DH13 borehole (Figure $2(\mathrm{~d})$ ). The deeper vein was observed at a relatively high-permeability depth (permeability coefficient of the DH-13 borehole: $1.3 \times 10^{-7} \mathrm{~m} / \mathrm{s}$ at a depth of $546-$ $616 \mathrm{~m}$ ) among the boreholes. This black glassy vein exhibited median-angle dips. No significant displacement of rocks on either side of the black glassy vein was observed, and no significant textures of shear or rotation were observed. Moreover, no significant continuous open fractures were found around the black glassy vein.

3.2. Mineral Mode and Microscopic Observation. Results of the mineral mode analysis obtained with the microscopic method by using thin sections of the borehole rock samples are shown in Figure 3 as modal compositions based on the Q-A-P diagram (IUGS classification following [38]). The mode of the DH-13 borehole showed relatively variable compositions, and near a depth of $330 \mathrm{~m}$, medium-grain quartz monzonite is observed. The mode of borehole $\mathrm{DH}-11$ is almost within the range of granite. Some noticeable changes in lithofacies were observed. The mode of the MIZ-1 borehole is attributed to various rock types, such as quartz-rich granitoids, monzonite, and quartz syenite.

Fine-grained minerals were observed in the black glassy vein of the DH-13 borehole. Microfractures were observed in and around the black glassy vein. Some continuous microfractures having a width of less than $1 \mathrm{~mm}$ were distributed in parallel within a range of several centimetres, and numerous branches were observed. Observation results of the polished rock samples indicate changes in the width of these 


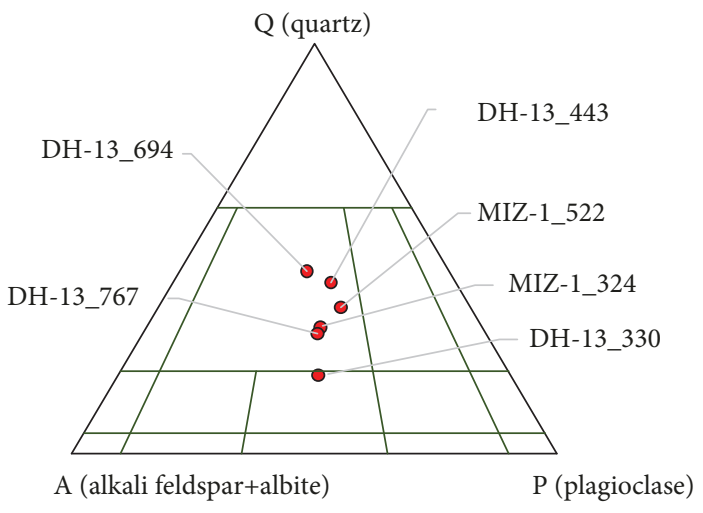

(a)

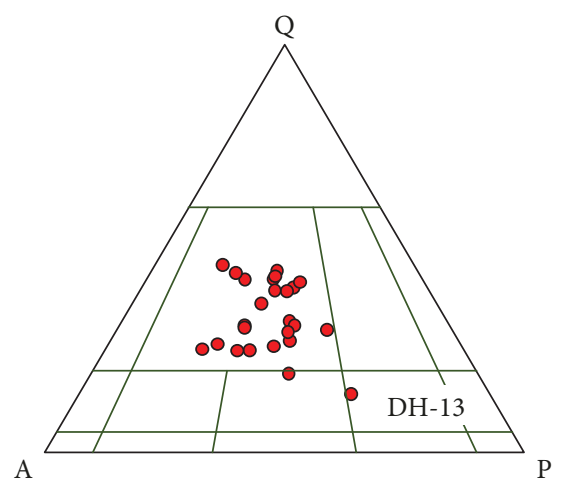

(c)

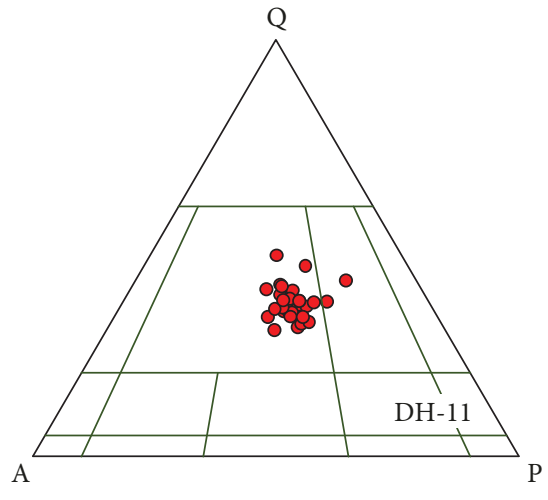

(b)

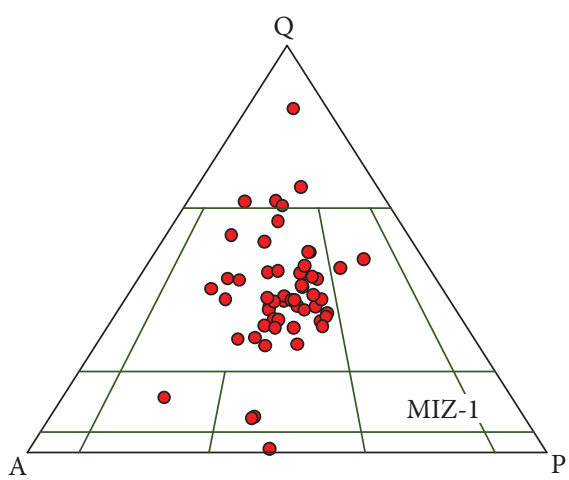

(d)

Figure 3: Mineral mode of rock core samples on the Q-A-P diagram (IUGS classification following [34]) based on the point-counting method of thin sections (more than 2000 counts each). (a) Mineral mode of the samples for EPMA. The borehole and depth in meters are indicated for the boreholes DH-13 and MIZ-1. (b-d) Mineral mode of other samples of DH-11, DH-13, and MIZ-1, respectively. Samples with a high $\mathrm{H}_{2} \mathrm{O}$ content $\left(\mathrm{H}_{2} \mathrm{O}>1.5 \%\right)$ are eliminated $(c, d)$.

microfractures by expansion and contraction (Figure 4(a)). The bulging part, in which quartz and feldspar mineral pieces were included, had a maximum width of $1.2 \mathrm{~mm}$. The texture did not indicate characteristics of shear motion, such as the rotation of mineral grains. A swarm of parallel microfractures was observed with a width of approximately $10 \mathrm{~mm}$, and a swarm of grain-boundary microfractures was observed with a width of approximately $20 \mathrm{~mm}$. These microfracture swarms having widths of approximately $20 \mathrm{~mm}$ constitute the black glassy vein.

Mainly fine-grained hornblendes and fine-grained anhedral quartz were observed in the black glassy vein (Figure 4(b)). Some dusty quartz in the vein exhibited an irregular fracture surface similar to cut surfaces. Fine hornblendes were found in grain boundaries of quartz in several instances. The texture did not indicate significant shearing or rotation. In the black glassy vein, euhedral hornblendes were partly recognized (Figure 4(b)-4(d)). These euhedral hornblendes were not broken. The length of the $c$ axis of the euhedral hornblende crystal was usually $5-40 \mu \mathrm{m}$, and a maximum length of $100 \mu \mathrm{m}$ was observed. The grain size of quartz is approximately $100 \mu \mathrm{m}$ in most cases, but some grains having sizes in the range of 5-50 $\mu \mathrm{m}$ were also recognized. In the black glassy vein, quartz grains approximately
$0.5-1 \mathrm{~mm}$ in size are often linked together in a line. Although microfractures developed in the quartz grains, filling minerals were not observed in numerous instances.

Muscovite and sericite are not observed in the microfractures, and secondary microfractures cut across the black glassy vein (Figure 4(c)). Secondary microfractures were filled with chlorite and calcite. Moreover, many microfractures developed in the host rock, and chlorite with altered biotite was observed in the host rock near the black glassy vein. Some of the biotite was altered and had a greenishbrown colour.

Various characteristics of fractures were observed in the MIZ-1 borehole. Chlorite, quartz, epidote, calcite, sericite, and smectite were observed in fractures as filling minerals of the MIZ-1 borehole. Filling minerals of quartz, calcite, and sericite were observed in layers in some of the open fractures. These results suggest multiple fluid-flow events. On the other hand, filling textures composed of biotite, quartz, and potassium feldspar were observed. The relationship between these characteristics of fractures and the permeability of the MIZ-1 borehole will be described later.

3.3. EPMA and Fluid-Inclusion Experiment. The chemical compositions of the minerals in the granite, quartz monzonite, 


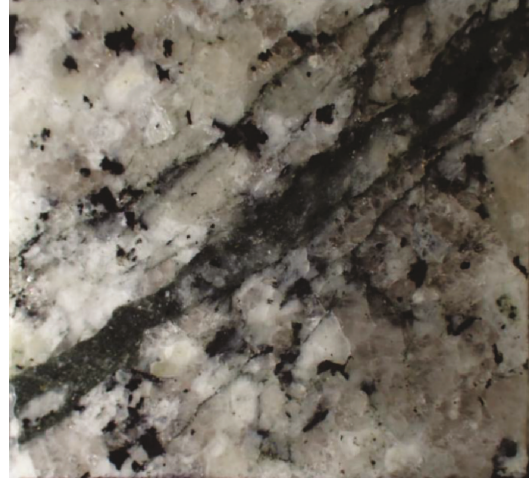

$5 \mathrm{~mm}$

(a)

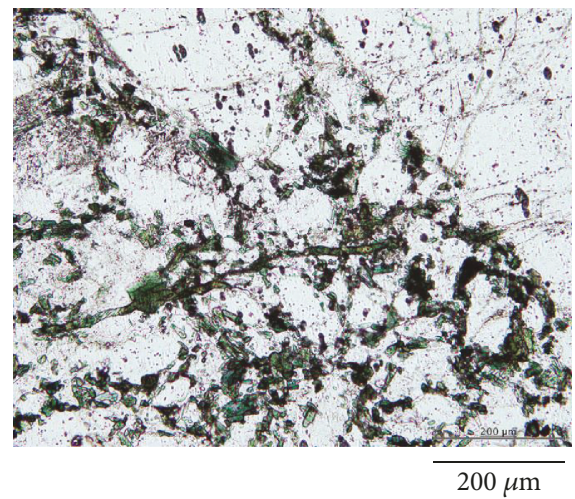

(c)

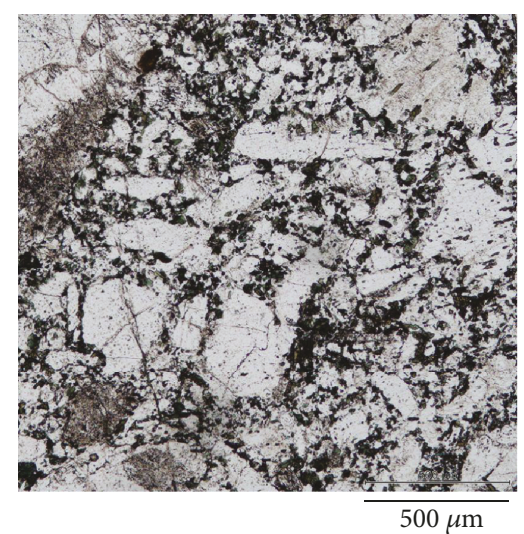

(b)

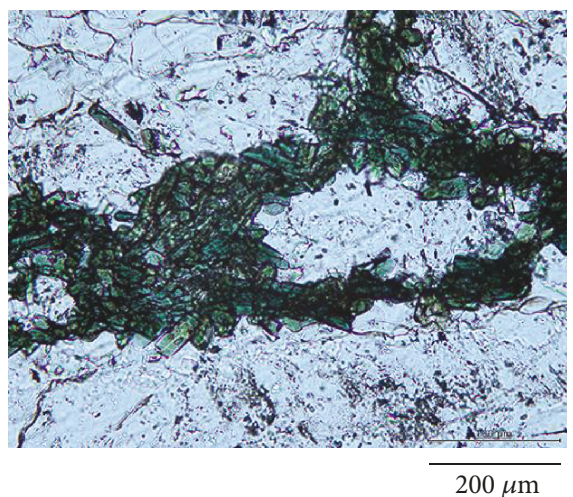

(d)

FIGURE 4: Close-up photograph and photomicrographs of the black glassy vein of Figure 2(d) (DH-13 553.87). (a) Close-up photograph of the black glassy vein (polished chip). (b) Quartz fragments and their bordering fine hornblende (thin section, open nicol). (c) Secondary microfracture (thin section, open nicol). (d) Euhedral hornblende aggregation (thin section, open nicol).

and vein were analysed using an electron probe microanalyser (EPMA; JEOL JXA-8200) at the Graduate School of Environmental Studies, Tohoku University, Japan. The EPMA analysis method was based on [17]. Plagioclase, amphibole, and biotite were analysed with an accelerating voltage of $15 \mathrm{kV}$, a beam current of $12 \mathrm{nA}$, a beam diameter of $1-5 \mu \mathrm{m}$, and a counting time of $10 \mathrm{~s}$. For analysing Ti concentrations in quartz, an accelerating voltage of $20 \mathrm{kV}$, a beam current of $100 \mathrm{nA}$, a beam diameter of $5 \mu \mathrm{m}$, and counting time of $300 \mathrm{~s}$ were used (cf. [39]).

Chemical zoning was found on X-ray maps of most of the plagioclase crystals; the core concentration of $\mathrm{Ca}$ tends to be high, and the rim tends to have a high $\mathrm{Na}$ concentration. The major Ti-containing minerals in the glassy vein were finegrained titanite, which showed a ubiquitous distribution within the veins.

Hereafter, analysed sample names indicate the borehole number followed by the depth in meters. The composition of plagioclase was mainly in the range of $X_{\mathrm{An}}[=\mathrm{Ca} /(\mathrm{Na}+$ $\mathrm{Ca})]=0.09-0.25$. The calcium concentration in some of the host rock plagioclase is remarkably higher than those in glassy veins (Figure 5(a)). Such host rock plagioclase shows high $X_{\text {An }}$ values in the range of $0.32-0.54$. The composition of plagioclase containing the euhedral crystals of amphibole $50-100 \mu \mathrm{m}$ in grain size is $X_{\mathrm{An}}=0.21-0.26$, and the compo- sition of plagioclase contacting the rim of amphibole grains is $X_{\text {An }}=0.13-0.24$ (DH-13 442.68). In contrast, plagioclase in the glassy vein tends to have a low- $X_{\mathrm{An}}$ rim. Coarse crystals with relatively high- $X_{\mathrm{An}}$ cores are surrounded by low- $X_{\mathrm{An}}$ rims, and fine-grained crystals tend to have a low $X_{\mathrm{An}}$ in the range of $0.12-0.29$, including one remarkably low $X_{\mathrm{An}}$ result of $0.005-0.055$ for DH-13 62.85 .

The Si contents of amphiboles are in the range of $\mathrm{Si}=$ 6.1-6.8 apfu, and according to the classification of Leake et al. [40], the amphiboles are classified as ferroedenite and ferropargasite (Figure 5(b)), both of which are referred to as "hornblende" in a broad sense hereafter. Furthermore, the $\mathrm{MnO}$ concentration is relatively high $(\mathrm{MnO}=1.3-$ 2.0 mass $\%)$. The hornblendes of the host rock have some zoning; $\mathrm{Al}$ is higher in the core and $\mathrm{Si}$ tends to be lower in the rim (DH-13 694.25). The hornblendes in the glassy vein had significantly lower $X_{\mathrm{Mg}}\left[=\mathrm{Mg} /\left(\mathrm{Mg}^{2+}+\mathrm{Fe}^{2+}\right)\right]$ values than the hornblendes in host rocks (host rock: 0.16-0.26; glassy vein: $0.14-0.18$ ). The $\mathrm{TiO}_{2}$ concentration in the hornblendes shows a bimodal distribution in the range of $0.26-$ 1.4 mass $\%$ with its boundary at 0.75 mass\% (Figure 6). The $\mathrm{TiO}_{2}$ concentration of the hornblendes (DH-13 330) coexisting with ilmenite was relatively high $(\sim 1.2$ mass $\%)$, and the $\mathrm{TiO}_{2}$ concentration of the hornblendes (DH-13 62.85) coexisting with the titanite was relatively low $(<0.5$ mass $\%)$. 


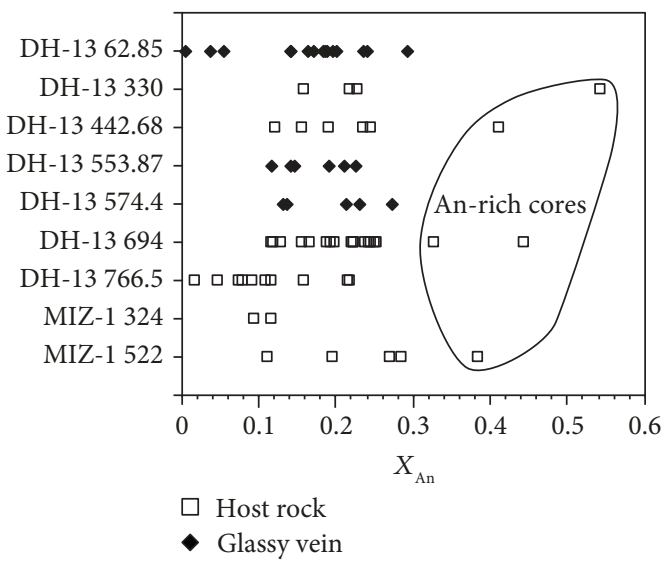

(a)

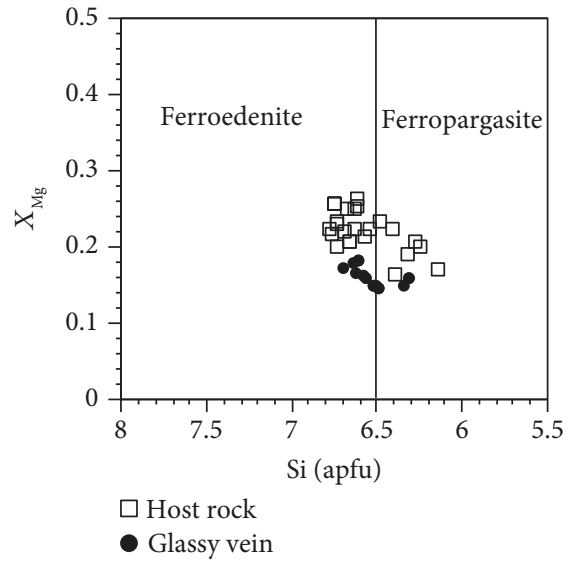

(b)

FIGURE 5: Chemical compositions of plagioclase and amphibole. (a) Ratio of anorthite composition in plagioclase $\left(X_{\mathrm{An}}\right.$ in boreholes DH-13 and MIZ-1). Each value on the right of the borehole code indicates the sampling depth. (b) Si apfu and $X_{\mathrm{Mg}}$ ratios of amphibole. White squares: host rock; solid circles: glassy veins.

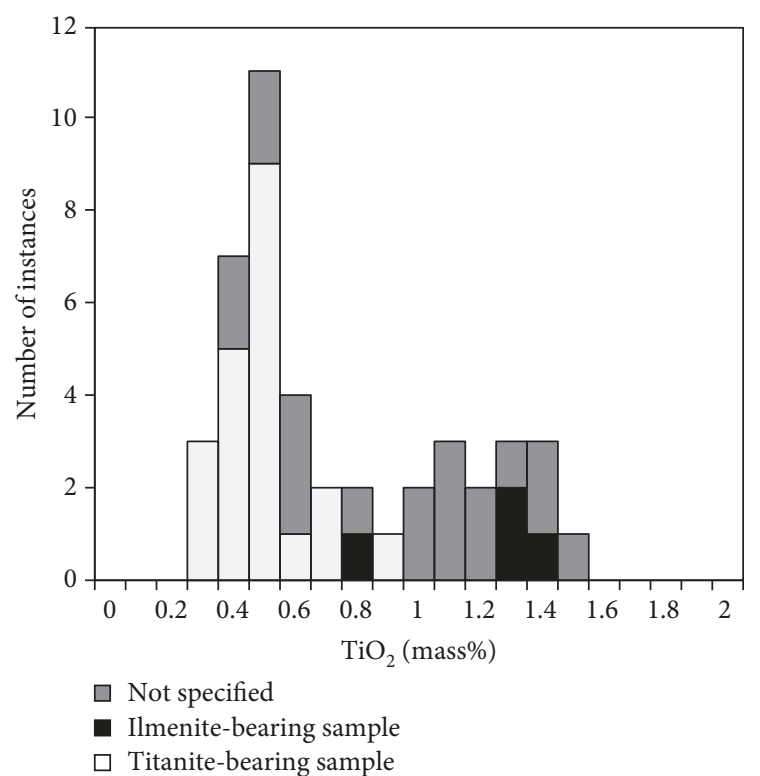

Figure 6: Frequency of $\mathrm{TiO}_{2}$ content in hornblende and types of coexisting titanium minerals.

For the biotite of the host rock, $X_{\mathrm{Mg}}=0.21-0.30$ and $\mathrm{TiO}_{2}=2.0-3.4$ mass $\%$. The $\mathrm{TiO}_{2}$ concentration tends to be high in the core and low in the rim. There is almost no difference in $X_{\mathrm{Mg}}$ between the core and the $\operatorname{rim}\left(\Delta X_{\mathrm{Mg}}<0.01\right)$. For the biotite in glassy veins, $X_{\mathrm{Mg}}=0.21-0.24$ and $\mathrm{TiO}_{2}=1.5$ -2.5 mass $\%$, and the $\mathrm{TiO}_{2}$ concentration was lower than in the biotite of the host rock in the same thin section.

$\mathrm{TiO}_{2}$ concentrations of the quartz in the medium-grain quartz monzonite containing the ilmenite were detected in 3 of the 4 analysis points and ranged from 29 to $83 \mathrm{ppm}$. For DH-13 442.68 and DH-13 694.25, where coexisting Ti minerals were not found, $\mathrm{TiO}_{2}$ was detected at only 2 of 19 analysis points, and the concentration ranged from 14$16 \mathrm{ppm}$. In the glassy veins, $\mathrm{TiO}_{2}$ was detected in 6 out of 20 points in the hornblende-bearing glassy vein coexisting with titanite, and its concentration was in the range of 16-97 ppm. $\mathrm{TiO}_{2}$ was not detected in the biotite-bearing glassy vein, and the coexisting Ti mineral was not recognized.

Temperature and pressure were estimated using amphibole-plagioclase thermometry [41] and Al-inhornblende barometry $[42,43]$. The hornblende and plagioclase pairs were chosen so that the rims were in contact with each other. For the hornblende cores, the compositions of the adjacent plagioclase cores were used. The temperature and pressure of the host rock were, respectively, estimated to be $3.3-4.5 \mathrm{kbar}$ and $694-730^{\circ} \mathrm{C}$ for $\mathrm{MIZ}-1$ and $4.0-7.6 \mathrm{kbar}$ and $654-742^{\circ} \mathrm{C}$ for $\mathrm{DH}-13$ (Figure $7(\mathrm{a})$ ). The hornblendes of $\mathrm{DH}-13$, which displayed a high pressure of $5.1 \mathrm{kbar}$ or more, had low $\mathrm{TiO}_{2}$ concentrations of $<0.75$ mass $\%$. For the hornblendes with a $\mathrm{TiO}_{2}$ concentration of 0.75 mass $\%$ or more, the pressure was within the range of 3.7-5.1 kbar. In hornblende inclusions in plagioclases, the temperature was higher near the core and lower in the rim $\left(657-730^{\circ} \mathrm{C}\right.$; DH13 442.68). Moreover, in hornblende grains, the temperature was higher in the core and lower in the $\operatorname{rim}\left(662-742^{\circ} \mathrm{C}\right.$; DH13 694.25). In the glassy vein, temperature and pressure ranges of $636-727^{\circ} \mathrm{C}$ and $4.6-7.3 \mathrm{kbar}$, respectively, were estimated. In addition, $\mathrm{TiO}_{2}$ concentrations in the glassy vein were all 0.7 mass $\%$ or less.

The temperature when the biotite formed was estimated using a Ti-in-biotite thermometer [44] (assuming $\alpha_{\mathrm{TiO} 2}=1$ ) as $599-682^{\circ} \mathrm{C}$ in the host rock (Figure $7(\mathrm{~b})$ ). This is slightly lower than the temperature $\left(662-742^{\circ} \mathrm{C}\right)$ determined using the amphibole-plagioclase thermometer. For the biotitebearing glassy vein, a temperature range of $534-633^{\circ} \mathrm{C}$ was estimated (DH-13 574.4). By using a Ti-in-quartz thermometer calibrated with procedures reported by Huang and Audétat [39], and assuming $\alpha_{\mathrm{TiO} 2}=1$, a temperature range of $606-706^{\circ} \mathrm{C}$ was estimated in the quartz of ilmenitebearing medium-grain quartz monzonite (DH-13 330). For host rock samples, the temperature was estimated to be $\sim 150^{\circ} \mathrm{C}$ lower than that of quartz monzonite. The temperatures of glassy veins were estimated to be $556-723^{\circ} \mathrm{C}$. The calibration procedures reported by Thomas et al. [45] 


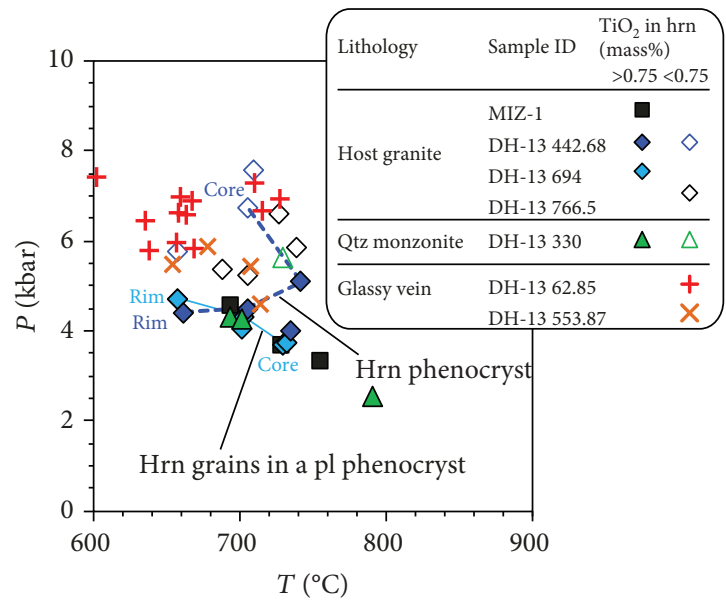

(a)

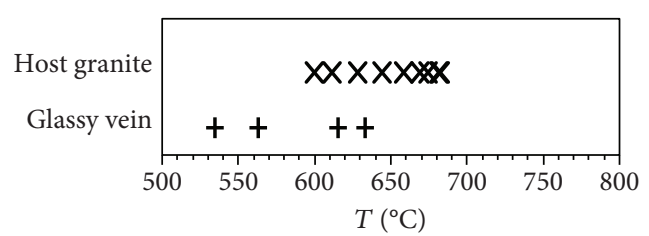

(b) Ti-in-biotite thermometer

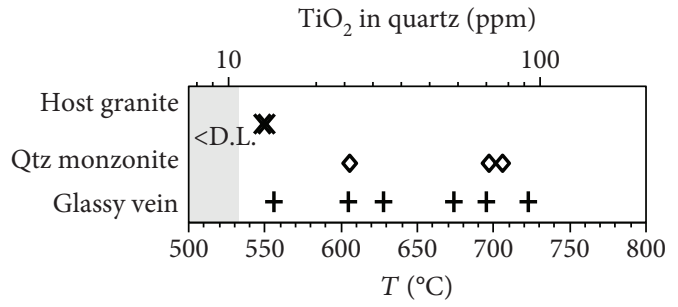

(c) Ti-in-quartz thermometer

Figure 7: Temperature and pressure estimation. (a) Temperature and pressure estimated using an amphibole-plagioclase thermometer [41] and Al-in-hornblende barometer [42]. (b) Temperature estimated using a Ti-in-biotite thermometer. (c) Temperature estimated using a Ti-in-quartz thermometer.

were used to estimate systematically lower temperatures $\left(\Delta T=100-150^{\circ} \mathrm{C}\right)$. Note that the temperatures obtained by Ti-in-quartz thermometry (assuming $\alpha_{\mathrm{TiO} 2}=1$ ) are minimum temperatures of quartz formation; this technique can underestimate temperatures $\sim 8-50^{\circ} \mathrm{C}$ for host granite and quartz monzonite, based on the $\alpha_{\mathrm{TiO} 2}$ ranges of ilmenitebearing felsic magmatic rocks (0.6-0.9; [46]). Glassy veins usually contain titanite but lack ilmenite or rutile, and the underestimation of temperature is possibly larger $\left(>50^{\circ} \mathrm{C}\right)$.

Fluid-inclusion microthermometry was employed to analyse the hornblende-bearing glassy veins. Measurements of the final melting of ice or halite $\left(T_{\mathrm{m}}\right)$ and the homogenization of vapor to liquid $\left(T_{\mathrm{h}}\right)$ were collected using a heating and cooling stage (LINKAM, LK-600) at the Graduate School of Environmental Studies, Tohoku University. The sizes of fluid inclusions ranged from 5 to $15 \mu \mathrm{m}$. Among these inclusions, relatively larger ones with irregular shapes stretched in one direction were observed in the black glassy veins. Most of the inclusions in the black glassy veins were relatively small. Repeated analyses of the same fluid inclusions suggest that the precision of the homogenization temperature was approximately $1^{\circ} \mathrm{C}$, though it was extremely difficult to determine the final melting of ice/halite for fluid inclusions of such small sizes and of irregular shapes. Most of the homogenization temperature ranged from 248 to $385^{\circ} \mathrm{C}$ (Figure 8(a)). The two low homogenization temperature data at $\sim 180^{\circ} \mathrm{C}$ are possibly from secondary fluid inclusions. The maximum value of the fluid-inclusion homogenization temperature was obtained in the black glassy vein (DH-13 553.87). This fluid inclusion was in a stretched form parallel to the black glassy vein.

Fluid-inclusion homogenization temperatures tend to be high near the boundary between the black glassy veins and host rock and relatively low near the centre of the black glassy vein. Both halite-saturated and nonhalite-saturated fluid inclusions were observed. The temperature of the final melting of ice was measured at areas in a good condition and was in the range of $-7^{\circ} \mathrm{C}$ to $-5^{\circ} \mathrm{C}$, but this needs further confirma- tion. Some fluid inclusions were halite-saturated, and the final melting of the halite was confirmed at $300^{\circ} \mathrm{C}$ or less. A $-7^{\circ} \mathrm{C}$ melting point of ice and $300^{\circ} \mathrm{C}$ melting point of halite correspond to 10.49 and 38 mass $\% \mathrm{NaCl}$, respectively $[47,48]$. The isochore was estimated at homogenization temperatures of $320^{\circ} \mathrm{C}, 350^{\circ} \mathrm{C}$, and $380^{\circ} \mathrm{C}$ with 0 to 40 mass $\%$ $\mathrm{NaCl}$ by using the state equation for $\mathrm{H}_{2} \mathrm{O}-\mathrm{NaCl}$ systems reported by Bowers and Helgeson [49]. The vapor pressure curve of the $\mathrm{H}_{2} \mathrm{O}-\mathrm{NaCl}$ system was modelled by [50]. The obtained isochore temperature was $580-750^{\circ} \mathrm{C}$, greater than $640^{\circ} \mathrm{C}$, and greater than $700^{\circ} \mathrm{C}$ for $T_{\mathrm{h}}=320^{\circ} \mathrm{C}, 350^{\circ} \mathrm{C}$, and $380^{\circ} \mathrm{C}$, respectively, at a pressure range of $3.2-5.2 \mathrm{kbar}$ (Figure 8(b)). These isochore ranges agree with the temperature and pressure conditions of formation of the host rock and glassy veins estimated from the composition of hornblende and plagioclase (Figure 8(b)).

3.4. P-T Condition of Glassy Vein. The Toki granitic body is composed mainly of granite, and there is a diversity of dikes of andesite to granodiorite. In addition, hydrothermal breccia veins and glassy veins accompanied by hornblendes were observed. The existence of such dikes and these characteristic veins indicated that fluid of relatively high temperature entered the granite. The temperature and pressure conditions of the fluid were estimated based on the results of analysing the host granite, intrusive medium-grain quartz monzonite, and glassy vein through EPMA analysis and the testing of fluid inclusions. By using an amphibole-plagioclase thermometer [41] and Al-in-hornblende barometer [42, 43] on the host rock and quartz monzonite rock, the temperature and pressure conditions were estimated using hornblendes in which the $\mathrm{TiO}_{2}$ concentration was greater than 0.8 mass $\%$ as well as the adjacent plagioclase. The result shows that the temperature and pressure are approximately $700^{\circ} \mathrm{C}$ and $4 \mathrm{kbar}$, respectively (Figure $7(\mathrm{a})$ ). In addition, the Ti-in-quartz thermometer calibrated by Huang and Audétat [39] was applied. Assuming $\alpha_{\mathrm{TiO} 2}=1$, the temperature of medium-grain quartz monzonite containing ilmenite (DH- 
(b1)

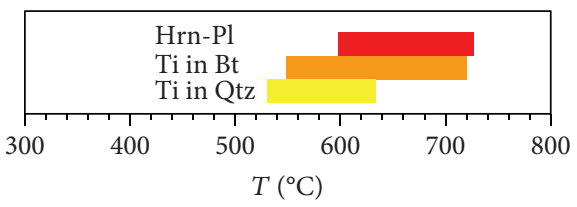

(b2)
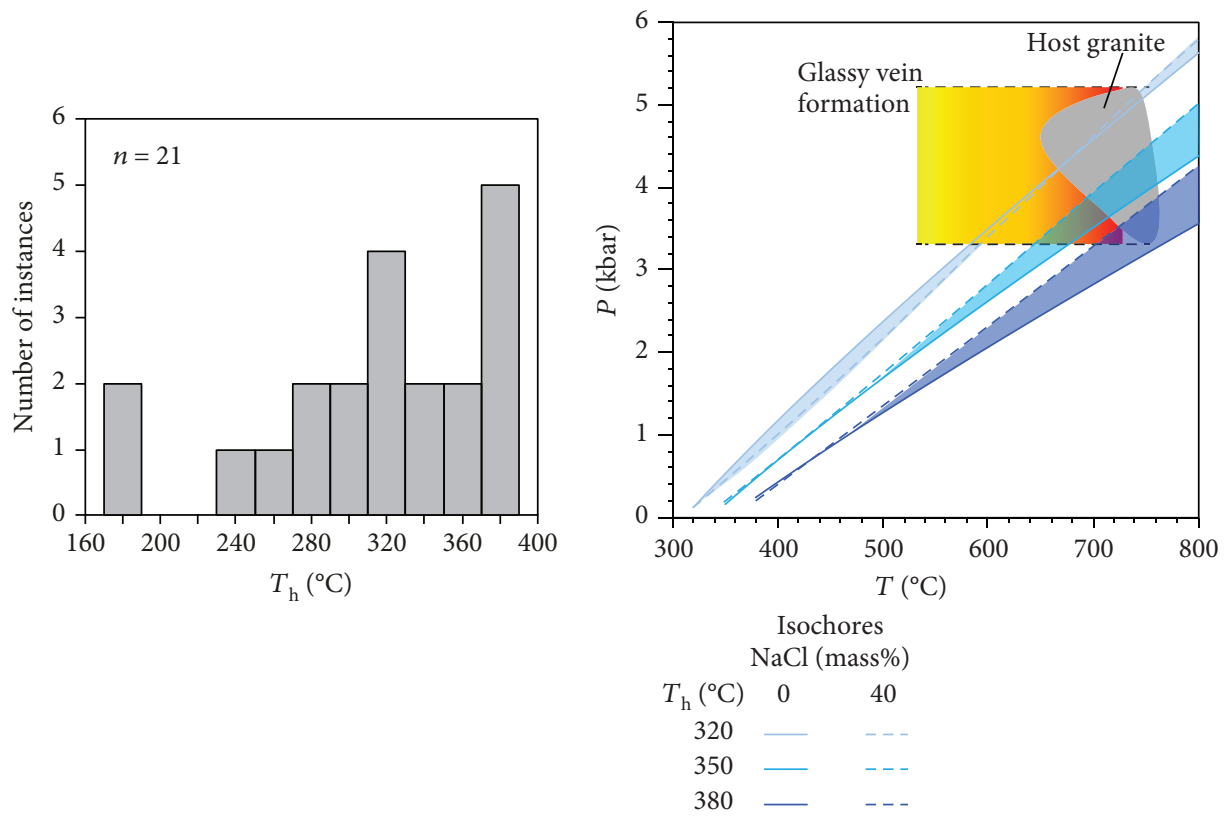

(a)

(b)

FIGURE 8: Homogenization temperatures of fluid inclusions and summary of $P-T$ conditions. (a) Histogram of $T_{\mathrm{h}}$ (homogenization) of fluid inclusions in glassy veins. (b) b1: summary of temperature constraints for glassy veins. b2: $P-T$ plot showing the conditions for the formation of the host granite, glassy veins, and fluid inclusions. The grey area indicates $P-T$ conditions of the host granite determined using the amphibole-plagioclase thermometer and Al-in-hornblende barometer. The area in red and orange indicates $P-T$ conditions for the glassyvein formation constrained by amphibole-plagioclase, Ti-in-biotite, and Ti-in-quartz thermometers.

13 330) was estimated to be in the range of $606-706^{\circ} \mathrm{C}$ (Figure 7(b)). Thus, the granite parent rock and mediumgrain quartz-monzonite intrusive rock are both estimated to have temperature and pressure conditions of approximately $700^{\circ} \mathrm{C}$ and $4 \mathrm{kbar}$, respectively. The emplacement condition of the Mitsuhashi granodiorite, which is approximately $20 \mathrm{~km}$ south of the Toki granite, is estimated to be 4 kbar [23]. These pressure conditions are consistent with those of the Toki granite.

Similarly, the temperature and pressure conditions of the glassy vein were estimated to be $636-727^{\circ} \mathrm{C}$ and $4.6-7.3 \mathrm{kbar}$, respectively. Since the $\mathrm{TiO}_{2}$ concentrations of these hornblendes were all 0.7 mass $\%$ or less, excess pressure values were obtained. As described below, if a glassy vein were formed in connection with the intrusion of medium-grain quartzmonzonite rock, the pressure would be similar to that of medium-grain quartz monzonite. Assuming a pressure of $4 \mathrm{kbar}$, the homogenization temperature of fluid inclusions of the quartz in the glassy vein was estimated to be approximately $700^{\circ} \mathrm{C}$ at maximum (Figure $8(\mathrm{~b})$ ). These values are consistent, and the temperature of the glassy vein is considered to be approximately $700^{\circ} \mathrm{C}$ at maximum. The glassy vein is a trace of the supercritical fluid that flowed into the Toki granite.
3.5. Track of Supercritical Fluid. The microscopic characteristics of the black glassy vein as a track of supercritical fluid were investigated. The formation of the black glassy vein observed around a depth of $550 \mathrm{~m}$ in the DH-13 borehole may be associated with fault movement accompanying an increase in crustal stress, in addition to the intrusion of high-temperature fluid in a geothermal system. A microfracture surface indicated a comparatively rugged shape, and there was an aggregation of euhedral hornblende (Figure 4(c)). This is evidence that the microfracture opened and the supercritical fluid flowed. The euhedral hornblende that precipitated in the black glassy vein was preserved.

On the other hand, the following characteristics of the black glassy veins imply shear events: (1) quartz particle fragments, (2) linear microfractures crossing dusty quartz crystals and feldspar, and (3) fine quartz particles. Among them, both fault movement and supercritical fluid were considered to cause (1). Quartz grain fragments surrounded by hornblende implied that the supercritical fluid flowed while the fragment formed. Microfractures were also observed in the grain boundary of the quartz crystal. Although the process of fracture formation by thermal shock was not indicated, the opening and cracking of grain boundaries, 
intragranular cracking, and mineral-grain dissection linked to the quartz $\alpha-\beta$ phase transition induced a significant increase in the total crack density [5]. Typical microfractures of quartz due to shear stress were distributed in a broom form from the apex [10], but such microfractures were not observed in the black glassy vein. No remarkable displacement or shear was recognized. This suggests that the quartz particle fragments (1) were formed by thermal shock, rather than shear events. Linear microfractures (2) exhibit a parallel microfracture swarm with hornblende precipitation. Parallel microfractures of metamorphic rocks have been reported to be tensile fractures associated with high-pore-pressure fluids [51]. The parallel microfractures were observed in the black glassy vein. Hornblende and quartz were often precipitated in the parallel microfractures and grain boundaries of quartz. These lines of evidence indicate that supercritical fluid was flowing. Regarding (3), both fine hornblende and fine quartz were observed in the black glassy vein, and most hornblendes in the black glassy vein have not been altered or destroyed. Since no texture suggesting wing shear or rotation was observed, these textures are not considered to be associated with shear stress. Rather, they are considered to have been formed at a relatively high temperature and recrystallized. There is no distribution of a shear zone that causes melting in this study area. Hence, these causes were reasonably assumed to be related to the heat and pressure accompanying the intrusion of the quartz monzonite and of the supercritical fluid, rather than fault movement alone.

Next, the timing and continuity of the events of the supercritical fluid are examined. In the Toki granitic body, the $\mathrm{Rb}$-Sr isotopic age of the initial minerals was estimated as $76.3 \pm 1.5 \mathrm{Ma}$, and the secondary minerals' age was estimated as $70.6 \pm 3.1 \mathrm{Ma}$. On this basis, it is thought that the episyenite alteration occurred approximately $70 \mathrm{Ma}$ ago [33]. Therefore, the events related to the supercritical fluid were considered to have occurred immediately after the setting of the Toki granitic body. The flow of the supercritical fluid was considered an episodic event with a limited duration, rather than a continuous one. Limited activities of the supercritical fluid were supported by its distribution features. Tracks of the supercritical fluid with amphiboles and feldspar were observed in a part of the $\mathrm{DH}-13$ borehole and distributed locally.

In summary, the glassy vein as the track of supercritical fluid showed characteristics of high-temperature hydrothermal fluid microfractures with filling minerals of amphibolite and feldspar. It was indicated that these microfractures were formed and preserved by the limited activity of the supercritical fluid immediately after granite setting.

\subsection{Relation between Permeability and Geothermal Fracturing.} The relationship between the formation and filling of fractures (including microfractures and microcracks) by supercritical fluid and water permeability was considered for the Toki granite. First, a microfracture that was formed by supercritical fluid is discussed. Etheridge et al. [51] suggested that microcracks formed by high-pore-pressure fluids and grain-edge tubules result in effective interconnected porosity. It is possible that the parallel microfractures and grain-boundary microfractures were formed by geothermal fracturing associated with the supercritical fluid flow through granite, following which effective interconnected porosity was preserved.

The DH-13 borehole displayed a relatively high permeability in all permeability tests. The rock around the black glassy vein also shows a high water permeability (permeability coefficient of the DH-13 borehole: $1.3 \times 10^{-7} \mathrm{~m} / \mathrm{s}$ at a depth of 546-616 m). For a width of approximately $20 \mathrm{~m}$ at depths centred on the black glassy vein, the loss of drilling water occurred during core extraction. A SEM image of microfracture was obtained using an electron probe microanalyser (EPMA; JEOL JXA-8530F) at the Tono Geoscience Centre, Japan Atomic Energy Agency. Evidence that an initial microfracture network, which was formed by geothermal fracturing associated with the supercritical fluid, was responsible for the current high permeability and porosity is summarized as follows.

First, in the black glassy vein, parallel microfractures were developed. The microfractures developed along the dusty quartz grain also developed in and around the black glassy vein (Figures 9(a) and 9(b)). These microfractures have characteristics of tensile microfractures developed by hightemperature geothermal fracturing, some of which were opened (Figure 9(c)). Therefore, these microfractures formed the initial microfracture network with effective interconnected porosity, which was formed by the supercritical fluid with partial filling.

Second, chloritization was observed in and around the black glassy vein, suggesting that the initial microfracture network caused chloritization as a permeable structure.

Third, the porosity at a depth of $550 \mathrm{~m}$ in the DH-13 borehole was approximately $3.6 \%$, and the density was in the range of $2.36-2.55 \mathrm{~g} / \mathrm{cm}^{3}$. These values show a relatively high porosity and low density in the Toki granite.

Fourth, the mesoscopic fracture distribution density is relatively low at this depth. No mesoscopic fracture network corresponding to the current high permeability and porosity was recognized. Moreover, no significant continuous open fracture corresponding to lost water was observed. Additionally, in the DH-13 borehole, no evidence of fault movement was recognized.

For comparison, thin sections from the $\mathrm{DH}-11$ borehole were observed at a depth of $500 \mathrm{~m}$, and the characteristics of a microfracture in and around the low-permeability feature was examined. This host rock displayed a relatively low permeability (permeability coefficient of the DH-11 borehole: $3.2 \times 10^{-9} \mathrm{~m} / \mathrm{s}$ at a depth of $\left.468-584 \mathrm{~m}\right)$. Consequently, in the DH-11 borehole, the open microfractures in and around the quartz grain were relatively less developed, though the secondary quartz that developed around the quartz grain boundary is conspicuous. Moreover, the secondary growth of biotite and/or chlorite was often observed outside the relict-shaped biotite (Figure 9(d)). The secondary mineral growth and transparency of the quartz grain may imply that textural equilibration occurred for a sufficient duration. It has been experimentally observed that, subsequent to chemical equilibration, textural equilibration results in the closure of pores, as well as the loss of connectivity between them [52]. The porosity was less than $1 \%$ and the 


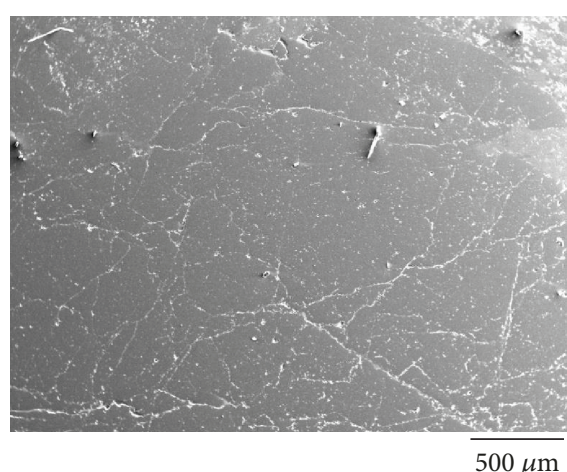

(a)

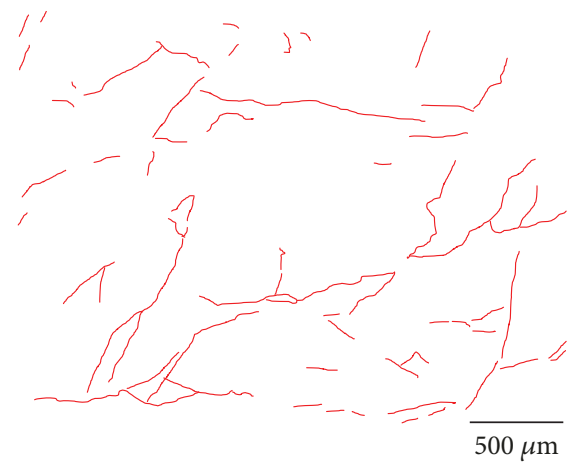

(c)

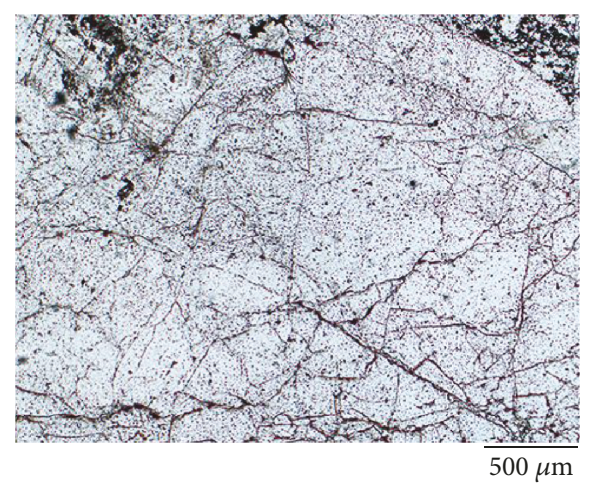

(b)

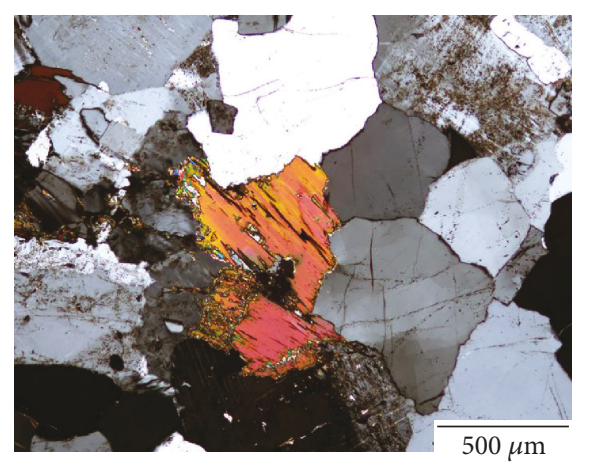

(d)

FIGURE 9: SEM image and photomicrographs of microfractures in the granite. (a) SEM image of developed open microfractures without filling minerals of the borehole DH-13 553.8. (b) Photomicrograph (thin section, open nicol) and (c) traced lines of these open microfractures. (d) Photomicrographs of fewer microfractures and second growth of the relict biotite of the borehole DH-11 537.2 (thin section, cross nicol).

density was approximately $2.56 \mathrm{~g} / \mathrm{cm}^{3}$ at a DH-11 borehole depth of approximately $500 \mathrm{~m}$.

In summary, it was shown that the initial microfracture network was formed by limited supercritical fluid flow. Subsequently, the preservation of the microfracture network was responsible for the high permeability of the present granite rock.

\subsection{Type Classification of Hydrothermal Fluid Fracture.} Hereafter, the mesofractures and microfractures accompanying the supercritical fluid and hydrothermal fluid activities are called hydrothermal fluid fracture. Hydrothermal fluid fracture includes hydrothermal convection fractures. Here, the relation between the permeability and characteristics of hydrothermal fluid fractures was considered. The result of the MIZ-1 borehole was expected to provide new insight into vertical changes. On the other hand, the layered filling minerals were indicative of multiple fluid-flow events. The limited supercritical fluid activity in the Toki granite was thought to have left unclear and complicated traces; therefore, a simple classification based on the characteristics of hydrothermal fluid fracture was attempted. The characteristics of the self-sealing zone were assumed based on Fournier [16] and were arranged based on the findings from the MIZ-1 borehole. According to Fournier [16], in an environment where a self-sealing zone and a glassy vein are formed with a supercritical fluid, the rapid flow of fluid, decompression, and destruction occur. Then, an increase in fluid pressure and temperature within the brittle domain leads to faulting and brecciation. In a self-sealing zone that was formed at the cooling stage of the Toki granitic body, a filling texture of fractures and microfractures and an accumulation texture associated with the supercritical fluid are expected to be observed. Observation results of the rock cores and thin sections showed these textures as the trace of a self-sealing zone near a depth of approximately $500 \mathrm{~m}$. Filling textures were observed in this trace. This texture was considered to be formed by traces of continuous open fractures filled by precipitation minerals of biotite, quartz, and potash feldspar. Similar precipitation minerals were observed in grainboundary microfractures in these textures. These precipitation minerals were recognized as precipitations associated with the supercritical fluids. The development of parallel microfractures was observed in quartz grains, which were often linked together in a line. These characteristics indicate that the black glassy vein is indeed the track of the supercritical fluid. Accumulation textures contained biotite-dominant and potash-feldspar-dominant layers. Ambiguous borders with the host rocks, quartz-dominant layers approximately $1 \mathrm{~cm}$ in thickness, and druse were often observed in these textures. No concentrated distributions of hydrothermal breccia veins or of quartz veins were observed in the trace. Hydrothermal breccia veins (Figure 2(b)) were observed in the vicinity of andesitic intrusive rock.

A simple type classification based on the assumption of supercritical fluid flow and its associated characteristics was 
TABle 1: Types of hydrothermal fluid fracture of the Toki granite. The characteristics of the fracture are shown based on data from three boreholes obtained in this study. The clay type was related to crustal deformation and erosion. Permeability was divided into three categories based on the existing in situ permeability test data [18].

\begin{tabular}{|c|c|c|c|c|c|c|}
\hline No. & $\begin{array}{l}\text { Type name } \\
\text { (short name) }\end{array}$ & $\begin{array}{c}\text { Veins } \\
\text { (main filling minerals) }\end{array}$ & $\begin{array}{l}\text { Mesofracture } \\
\text { (microfracture) }\end{array}$ & $\begin{array}{l}\text { Fracture density } \\
\text { (microfracture) }\end{array}$ & Permeability & Metamorphic facies \\
\hline I & Microfracture type & $\begin{array}{l}\text { Glassy vein (hornblende, } \\
\text { plagioclase, quartz, } \\
\text { K-feldspar) }\end{array}$ & $\begin{array}{c}\text { Parallel fracture } \\
\text { (microfracture network) }\end{array}$ & Small (large) & High & Amphibolite \\
\hline II & $\begin{array}{l}\text { Self-sealing type } \\
\text { (sealing type) }\end{array}$ & $\begin{array}{l}\text { Quartz vein, filling texture } \\
\text { (biotite, quartz, K-feldspar) }\end{array}$ & $\begin{array}{l}\text { Minor (grain boundary } \\
\text { microfracture, parallel } \\
\text { microfracture) }\end{array}$ & Small (large) & Low & $\begin{array}{l}\text { Epidote-amphibolite, } \\
\text { partly greenschist }\end{array}$ \\
\hline III & $\begin{array}{l}\text { Initial fracture type } \\
\text { (initial type) }\end{array}$ & $\begin{array}{l}\text { Quartz vein, filling texture, } \\
\text { sericite filling (chlorite, } \\
\text { quartz, } \\
\text { K-feldspar, epidote, sericite, } \\
\text { calcite) }\end{array}$ & $\begin{array}{l}\text { Low- to middle-angle } \\
\text { fractures (parallel } \\
\text { microfracture) }\end{array}$ & Small & Medium & $\begin{array}{l}\text { Epidote-amphibolite, } \\
\text { partly greenschist }\end{array}$ \\
\hline IV & $\begin{array}{l}\text { Chlorite filling type } \\
\text { (chlorite type) }\end{array}$ & $\begin{array}{l}\text { Chlorite filling, filling texture } \\
\text { (chlorite, quartz, K-feldspar, } \\
\text { epidote) }\end{array}$ & $\begin{array}{l}\text { High-angle fracture with } \\
\text { displacement, open } \\
\text { fracture } \\
\text { (parallel microfracture) }\end{array}$ & Small & High & $\begin{array}{l}\text { Epidote-amphibolite, } \\
\text { partly greenschist }\end{array}$ \\
\hline $\mathrm{V}$ & $\begin{array}{l}\text { Sericite filling type } \\
\text { (sericite type) }\end{array}$ & $\begin{array}{c}\text { Sericite filling, brecciated } \\
\text { glassy } \\
\text { vein (sericite, calcite, albite) }\end{array}$ & $\begin{array}{c}\text { Fracture network with } \\
\text { low- to middle-angle } \\
\text { open } \\
\text { fractures }\end{array}$ & Large & High & Greenschist \\
\hline VI & $\begin{array}{c}\text { Smectite sealing } \\
\text { type } \\
\text { (clay type) }\end{array}$ & $\begin{array}{c}\text { Brecciated glassy vein } \\
\text { (smectite, sericite, calcite) }\end{array}$ & Smectite filling fracture & Large & Low & - \\
\hline
\end{tabular}

proposed, as summarized in Table 1. The types are indicated by short names in the table. Five types of hydrothermal fluid fractures (microfracture type, sealing type, initial type, chlorite type, and sericite type) were set, assuming the following geological conditions in and around the selfsealing zone: First, most of the filling minerals remained in the precipitation condition. Second, some of the grainboundary microfractures associated with the supercritical fluid were filled during the formation of the self-sealing zone. Third, a part of the glassy vein immediately above the self-sealing zone formed a secondary high-angle open fracture. Fourth, a fracture network was developed by decompression and destruction above the self-sealing zone under a brittle condition.

The metamorphic facies [53] was used to confirm relative temperatures from the major precipitated minerals. The microfracture type was unique to the $\mathrm{DH}-13$ borehole. The black glassy vein containing hornblende and plagioclase showed a geological condition of $700^{\circ} \mathrm{C}$ at $4 \mathrm{kbar}$. The other four types were recognized in the MIZ-1 borehole. The low permeability of the self-sealing zone was usually formed along an isotemperature zone of approximately $400^{\circ} \mathrm{C}$ associated with the supercritical fluid, which corresponded to the boundary between the lithostatic and the hydrostatic pressure (e.g., [16]). The sealing type corresponded to the trace of the self-sealing zone. The chlorite type was characterized by high-angle fractures and filling minerals of chlorite, quartz, potassium feldspar, and epidote near a depth of approximately $400 \mathrm{~m}$. These fractures were often accompanied by continuous open high-angle fractures, which often showed a small displacement. Moreover, numerous parallel microfractures in quartz crystals were observed. These characteristics imply decompression and destruction associated with the supercritical fluid and rapid flow of the fluid. The sericite type was characterized by a fracture network accompanied by low-angle open fractures, which were observed near a depth of approximately $300 \mathrm{~m}$ and approximately 600-700 m. The deeper observations, accompanied by hydrothermal alteration, suggest that limited hydrothermal convection occurred after cooling, but a part of the trace of the self-sealing zone was preserved. The initial type was considered as an intermediate type between the sealing type and sericite type (or the chlorite type), and it was observed near the sealing type. Quartz veins were observed in the initial type and sealing type. The clay type related to the crustal deformation was recognized near a depth of approximately $950 \mathrm{~m}$. It was considered that brecciated glassy veins were related to crustal deformation.

The permeability and fracture distribution of these five types were clearly distinguished (Figure 10). The sealing type corresponded to a low permeability and few fractures, the chlorite type corresponded to a high permeability and few fractures, and the sericite type corresponded to a high permeability and many fractures. It was indicated that the difference of four orders in the permeability coefficient values was related to the difference in the characteristics of hydrothermal fluid fracture formed in and around the trace of the self-sealing zone. The results of this study indicate that the enhancement of permeability was activated by the supercritical fluid flow through granite. 


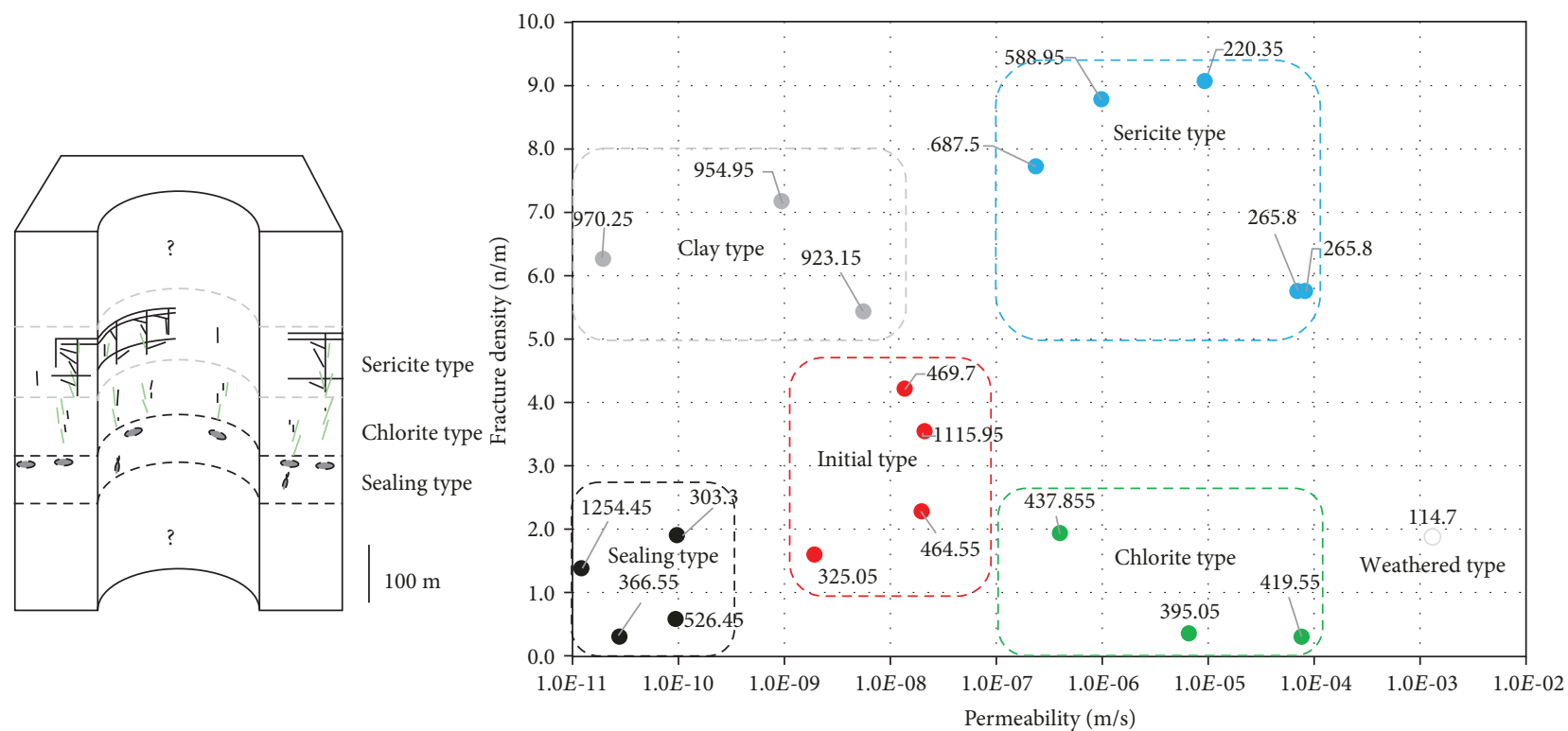

FIGURE 10: Relationship between the hydraulic conductivity and fracture density of the MIZ-1 borehole. The extents of four types of hydrothermal fluid fracture and a clay type are each surrounded by dotted and coloured boxes. Small numbers show the centre depth of each hydraulic test section. A schematic distribution of three representative types (sealing type, chlorite type, and sericite type) are shown on the right side. A weathered type was recognized as an outlier; this fracture probably experienced stress relief beneath the unconformity.

\section{Conclusion}

Characteristics of veinlets and fractures were examined using borehole rock cores in the Toki granite, and the relationship between their forming condition and permeability was investigated. As a result of core observation, quartzmonzonite intrusive rock, hydrothermal breccia veins, and glassy veins were investigated. The results of this study indicate that the glassy veins, which are composed of hornblende and quartz, are traces of a high-temperature fluid that flowed in the granite. As a result of applying amphibole-plagioclase thermometry, Al-in-hornblende barometry, and Ti-inquartz thermometry to the granite host rock and quartzmonzonite intrusive rock, the temperature and pressure conditions were estimated to be approximately $700^{\circ} \mathrm{C}$ and $4 \mathrm{kbar}$. The maximum temperature of the glassy vein was estimated to be approximately $700^{\circ} \mathrm{C}$. Existing $\mathrm{Sr}$ isotopic dating data showed the timing of the hydrothermal event $(70 \mathrm{Ma})$ to be immediately after granite setting $(76 \mathrm{Ma})$. The glassy vein with hornblende and plagioclase was identified to be the track of the supercritical fluid flowing in the Late Cretaceous.

The grain-boundary microfractures and parallel microfractures were recognized as traces formed and preserved by the limited activity of supercritical fluid flow immediately after the setting of granite. These microfractures formed a network and were associated with the current high permeability and porosity. In order to investigate the relationship between the trace of the supercritical fluid and the current permeability, characteristics of hydrothermal fluid fracture were investigated using rock cores of the borehole at a depth of $1200 \mathrm{~m}$. Observation results of the rock cores and thin sections showed the trace of a self-sealing zone near a depth of approximately $500 \mathrm{~m}$. In this trace, fill- ing textures composed of biotite, quartz, and potassium feldspar were observed. These textures were considered as traces of continuous open fractures filled by precipitation minerals. Similar precipitation minerals were observed in grain-boundary microfractures in these textures. The development of parallel microfractures was observed in quartz grains, which were often linked together in a line. These characteristics indicated that the black glassy vein is the track of the supercritical fluid.

Five types of hydrothermal fluid fracture were proposed based on the permeability of each test section and the characteristics of hydrothermal fluid fracture of the DH-13 and MIZ-1 boreholes. The permeability and fracture distribution of these types were clearly distinguished. The sealing type corresponded to a low-permeability section in which the filling textures were observed. The chlorite type corresponded to a high-permeability section that showed a small displacement of chlorite-filling high-angle fractures accompanied by high-angle open fractures. The sericite type corresponded to high-permeability sections, and a fracture network accompanied by low-angle open fractures was observed in these sections. The initial type was considered an intermediate between the sealing type and sericite type. Quartz veins were observed in the initial type and sealing type.

The results of this geological investigation allow the identification of traces of microfractures and fractures associated with supercritical fluid flow. This study presented examples showing the relationship between the trace of supercritical fluid flowing through granite and the enhancement of permeability in a mobile belt, based on limited data from boring surveys. It was indicated that the difference of four orders in the permeability coefficient values is related to the difference in the characteristics of hydrothermal fluid fracture in and around the self-sealing zone. 


\section{Data Availability}

(1) The EPMA data used to support the findings of this study are included within the supplementary information (available here). (2) The fracture distribution data used to support the findings of this study are included within the supplementary information. (3) The previously reported borehole permeability test data used to support this study are available at doi:10.11484/jaea-data-code-2016-012. These prior studies and datasets are cited at relevant places within the text as references.

\section{Disclosure}

This research was not performed as part of the employment of the authors.

\section{Conflicts of Interest}

The authors declare that there is no conflict of interest regarding the publication of this paper.

\section{Acknowledgments}

We thank Prof. Yoshikuni Hiroi (National Institute of Polar Research), Dr. Mayuko Shimizu, and Ms. Naomi Sano (JAEA) for helpful discussions and Mr. T. Sakai for the support with rock specimens and data preparation.

\section{Supplementary Materials}

Data tables of EPMA analysis Appendix Table 1: representative composition of amphibole within the host granite and glassy veins (1/2) and (2/2). Appendix Table 2: representative composition of plagioclase within the host granite and glassy veins (1/2) and (2/2). Appendix Table 3: representative composition of biotite within the host granite and glassy veins. Data table of hydrothermal fluid fracture types Appendix Table 4: hydrothermal fluid fracture types and permeability of the MIZ-1 borehole. (Supplementary Materials)

\section{References}

[1] Japan Nuclear Cycle Development Institute, H12: Project to Establish the Scientific and Technical Basis for HLW Disposal in Japan: Supporting Report 1, Geological Environment in Japan, Japan Nuclear Cycle Development Institute, 2000.

[2] A. Nagatomo and H. Yoshida, "Analysis of the geological history of the active Atera fault, central Japan, based on fault and fracture systems and infilling minerals," The Journal of the Geological Society of Japan, vol. 115, no. 10, pp. 512-527, 2009.

[3] H. Takagi, S. Miwa, Y. Yokomizo et al., "Estimation of the paleostress field from the 3-D orientation distribution of microcracks and their geothermal conditions in the Toki granite, central Japan," The Journal of the Geological Society of Japan, vol. 114, no. 7, pp. 321-335, 2008.

[4] C. H. Scholz, N. H. Dawers, J. Z. Yu, M. H. Anders, and P. A. Cowie, "Fault growth and fault scaling laws: preliminary results," Journal of Geophysical Research: Solid Earth, vol. 98, no. B12, pp. 21951-21961, 1993.
[5] M. H. B. Nasseri, A. Schubnel, and R. P. Young, "Coupled evolutions of fracture toughness and elastic wave velocities at high crack density in thermally treated Westerly granite," International Journal of Rock Mechanics and Mining Sciences, vol. 44, no. 4, pp. 601-616, 2007.

[6] M. Bando, G. Bignall, K. Sekine, and N. Tsuchiya, "Petrography and uplift history of the Quaternary Takidani Granodiorite: could it have hosted a supercritical (HDR) geothermal reservoir?," Journal of Volcanology and Geothermal Research, vol. 120, no. 3-4, pp. 215-234, 2003.

[7] S. Kano and N. Tsuchiya, "Parallelepiped cooling joint and anisotropy of P-wave velocity in the Takidani granitoid, Japan Alps," Journal of Volcanology and Geothermal Research, vol. 114, no. 3-4, pp. 465-477, 2002.

[8] B. J. Kowallis and H. F. Wang, "Microcrack study of granitic cores from Illinois deep borehole UPH 3," Journal of Geophysical Research: Solid Earth, vol. 88, no. B9, pp. 73737380, 1983.

[9] J. P. Evans, "Deformation mechanisms in granitic rocks at shallow crustal levels," Journal of Structural Geology, vol. 10, no. 5, pp. 437-443, 1988.

[10] U. Akesson, J. Hansson, and J. Stigh, "Characterisation of microcracks in the Bohus granite, western Sweden, caused by uniaxial cyclic loading," Engineering Geology, vol. 72, no. 1-2, pp. 131-142, 2004.

[11] C. Janssen, F. Wagner, A. Zang, and G. Dresen, "Fracture process zone in granite: a microstructural analysis," International Journal of Earth Sciences, vol. 90, no. 1, pp. 46-59, 2001.

[12] T. Esaki, H. Hojo, T. Kimura, and N. Kameda, "Shear-flow coupling test on rock joints," in 7th ISRM Congress, pp. 389392, International Society for Rock Mechanics and Rock Engineering, Aachen, Germany, 1991.

[13] X.-Q. Wang, A. Schubnel, J. Fortin, Y. Guéguen, and H. K. Ge, "Physical properties and brittle strength of thermally cracked granite under confinement," Journal of Geophysical Research: Solid Earth, vol. 118, no. 12, pp. 6099-6112, 2013.

[14] N. Watanabe, T. Numakura, K. Sakaguchi et al., "Potentially exploitable supercritical geothermal resources in the ductile crust," Nature Geoscience, vol. 10, no. 2, pp. 140-144, 2017.

[15] C. E. Manning and S. E. Ingebritsen, "Permeability of the continental crust: implications of geothermal data and metamorphic systems," Reviews of Geophysics, vol. 37, no. 1, pp. 127150, 1999.

[16] R. O. Fournier, "Hydrothermal processes related to movement of fluid from plastic into brittle rock in the magmaticepithermal environment," Economic Geology, vol. 94, no. 8, pp. 1193-1211, 1999.

[17] N. Tsuchiya, R. Yamada, and M. Uno, "Supercritical geothermal reservoir revealed by a granite-porphyry system," Geothermics, vol. 63, pp. 182-194, 2016.

[18] H. Onoe and R. Takeuchi, Results of Single Borehole Hydraulic Tests in the Mizunami Underground Research Laboratory Project. FY 2012 - FY 2015, (No. JAEA-DATA/CODE-2016-012), Japan Atomic Energy Agency, 2016.

[19] S. Ishihara and Y. Suzuki, "Basement granites of the Toki uranium deposits in Tono region," Reports, Grological Survey of Japan, vol. 232, pp. 113-127, 1969.

[20] S. Ishihara and S. Terashima, "The tin content of the Japanese granitoids and its geological significance on the Cretaceous magmatism," Journal of Geological Society of Japan, vol. 83, pp. 657-664, 1977. 
[21] T. Yamasaki, "K-Ar ages of the Ryoke plutonic rocks in the Asuke area, Aichi prefecture, central Japan," The Journal of the Geological Society of Japan, vol. 119, no. 6, pp. 421-431, 2013.

[22] K. Miyazaki, "Development of migmatites and the role of viscous segregation in high- $T$ metamorphic complexes: example from the Ryoke Metamorphic Complex, Mikawa Plateau, Central Japan," Lithos, vol. 116, no. 3-4, pp. 287-299, 2010.

[23] T. Kutsukake, "The depth of emplacement of the Mitsuhashi granite pluton in the Ryoke Belt, central Japan - as inferred from some geobarometric calibrations," The Journal of the Geological Society of Japan, vol. 103, no. 6, pp. 604607, 1997.

[24] T. Sonehara and S. Harayama, "Petrology of the Nohi Rhyolite and its related granitoids: a Late Cretaceous large silicic igneous field in central Japan," Journal of Volcanology and Geothermal Research, vol. 167, no. 1-4, pp. 57-80, 2007.

[25] T. Yuguchi, K. Amano, T. Tsuruta, T. Danhara, and T. Nishiyama, "Thermochronology and the threedimensional cooling pattern of a granitic pluton: an example from the Toki granite, Central Japan," Contributions to Mineralogy and Petrology, vol. 162, no. 5, pp. 1063-1077, 2011.

[26] K. Wakita, "Melanges of the Mino terrane," Memoir of Geological Society of Japan, vol. 55, pp. 145-163, 2000.

[27] T. Yuguchi, T. Tsuruta, and T. Nishiyama, "Zoning of rock facies and chemical composition in the Toki granitic body, Central Japan," Japanese Magazine of Mineralogical and Petrological Sciences, vol. 39, no. 2, pp. 50-70, 2010.

[28] T. Oikawa, H. Mashima, A. Tanase, A. Ninomiya, and K. Umeda, "K-Ar age of high magnesium andesite dikes at the Toki River in Gifu Prefecture, Central Japan," The Journal of the Geological Society of Japan, vol. 112, no. 10, pp. 616-619, 2006.

[29] T. Sakai, T. Nohara, and M. Ishibashi, Development of Geological Models in the Mizunami Underground Research Laboratory Project. Updating from 'Shaft500 Geological Model' to 'Stage500 Geological Model' in Phase II. JAEA-RESEARCH, (2016-009), Japan Atomic Energy Agency, 2016.

[30] Y. Fujii, "Fracture analysis of the Toki granite in the Tono district, central Japan," The Journal of the Geological Society of Japan, vol. 106, no. 4, pp. 249-263, 2000.

[31] J. Itoigawa, "Geology of the Mizunami district, central Japan. Monogr,” Mizunami Fossil Museum, vol. 1, pp. 1-42, 1980.

[32] T. Kobayashi, "Geology and uranium mineralization in the eastern part of the Kani basin, Gifu, Central Japan.," Mining Geology, vol. 39, no. 214, pp. 79-94, 1989.

[33] S. Nishimoto, H. Yoshida, Y. Asahara, T. Tsuruta, M. Ishibashi, and N. Katsuta, "Episyenite formation in the Toki granite, Central Japan," Contributions to Mineralogy and Petrology, vol. 167, no. 1, p. 960, 2014.

[34] T. Yuguchi, E. Sasao, M. Ishibashi, and T. Nishiyama, "Hydrothermal chloritization processes from biotite in the Toki granite, central Japan: temporal variations of of the compositions of hydrothermal fluids associated with chloritization," American Mineralogist, vol. 100, no. 5-6, pp. 1134-1152, 2015.

[35] S. Nishimoto and H. Yoshida, "Hydrothermal alteration of deep fractured granite: effects of dissolution and precipitation," Lithos, vol. 115, no. 1-4, pp. 153-162, 2010.

[36] T. Nohara, Y. Ochiai, T. Seo, and H. Yoshida, "Uranium-series disequilibrium studies in the Tono uranium deposit, Japan," Radiochimica Acta, vol. 58-59, no. 2, 1992.
[37] P. A. Domenico and F. W. Schwartz, Physical and Chemical Hydrogeology, John Wiley, 1990.

[38] A. Streckeisen, "Classification and nomenclature of plutonic rocks recommendations of the IUGS subcommission on the systematics of igneous rocks," Geologische Rundschau, vol. 63, no. 2, pp. 773-786, 1974.

[39] R. Huang and A. Audétat, "The titanium-in-quartz (TitaniQ) thermobarometer: a critical examination and re-calibration," Geochimica et Cosmochimica Acta, vol. 84, pp. 75-89, 2012.

[40] B. E. Leake, A. R. Woolley, C. E. S. Arps et al., "Nomenclature of amphiboles; report of the subcommittee on amphiboles of the international mineralogical association commission on new minerals and mineral names," Mineralogical Magazine, vol. 61, no. 405, pp. 295-310, 1997.

[41] T. Holland and J. Blundy, "Non-ideal interactions in calcic amphiboles and their bearing on amphibole-plagioclase thermometry," Contributions to Mineralogy and Petrology, vol. 116, no. 4, pp. 433-447, 1994.

[42] J. L. Anderson and D. R. Smith, "The effects of temperature and $\mathrm{fO} 2$ on the Al-in-hornblende barometer," American Mineralogist, vol. 80, no. 5-6, pp. 549-559, 1995.

[43] M. W. Schmidt, "Amphibole composition in tonalite as a function of pressure: an experimental calibration of the Alin-hornblende barometer," Contributions to Mineralogy and Petrology, vol. 110, no. 2-3, pp. 304-310, 1992.

[44] D. J. Henry, C. V. Guidotti, and J. A. Thomson, "The Tisaturation surface for low-to-medium pressure metapelitic biotites: implications for geothermometry and Ti-substitution mechanisms," American Mineralogist, vol. 90, no. 2-3, pp. 316-328, 2005.

[45] J. B. Thomas, E. Bruce Watson, F. S. Spear, P. T. Shemella, S. K. Nayak, and A. Lanzirotti, "TitaniQ under pressure: the effect of pressure and temperature on the solubility of Ti in quartz," Contributions to Mineralogy and Petrology, vol. 160, no. 5, pp. 743-759, 2010.

[46] M. S. Ghiorso and G. A. R. Gualda, "A method for estimating the activity of titania in magmatic liquids from the compositions of coexisting rhombohedral and cubic iron-titanium oxides," Contributions to Mineralogy and Petrology, vol. 165, no. 1, pp. 73-81, 2013.

[47] R. J. Bodnar, "Revised equation and table for determining the freezing point depression of $\mathrm{H}_{2} \mathrm{O}-\mathrm{NaCl}$ solutions," Geochimica et Cosmochimica Acta, vol. 57, no. 3, pp. 683-684, 1993.

[48] S. M. Sterner, D. L. Hall, and R. J. Bodnar, "Synthetic fluid inclusions. V. Solubility relations in the system $\mathrm{NaCl}-\mathrm{KCl}$ $\mathrm{H}_{2} \mathrm{O}$ under vapor-saturated conditions," Geochimica et Cosmochimica Acta, vol. 52, no. 5, pp. 989-1005, 1988.

[49] T. S. Bowers and H. C. Helgeson, "Calculation of the thermodynamic and geochemical consequences of nonideal mixing in the system $\mathrm{H}_{2} \mathrm{O}-\mathrm{CO}_{2}-\mathrm{NaCl}$ on phase relations in geologic systems: equation of state for $\mathrm{H}_{2} \mathrm{O}-\mathrm{CO}_{2}-\mathrm{NaCl}$ fluids at high pressures and temperatures," Geochimica et Cosmochimica Acta, vol. 47, no. 7, pp. 1247-1275, 1983.

[50] T. Driesner and C. A. Heinrich, "The system $\mathrm{H}_{2} \mathrm{O}-\mathrm{NaCl}$. Part I: correlation formulae for phase relations in temperaturepressure-composition space from 0 to $1000^{\circ} \mathrm{C}, 0$ to 5000 bar, and 0 to $1 X_{\mathrm{NaCl}}$," Geochimica et Cosmochimica Acta, vol. 71, no. 20, pp. 4880-4901, 2007.

[51] M. A. Etheridge, V. J. Wall, S. F. Cox, and R. H. Vernon, "High fluid pressures during regional metamorphism and deformation: implications for mass transport and deformation 
mechanisms," Journal of Geophysical Research: Solid Earth, vol. 89, no. B6, pp. 4344-4358, 1984.

[52] C. V. Putnis, K. Tsukamoto, and Y. Nishimura, "Direct observations of pseudomorphism: compositional and textural evolution at a fluid-solid interface," American Mineralogist, vol. 90, no. 11-12, pp. 1909-1912, 2005.

[53] A. Miyashiro, Metamorphic rocks and metamorphic belts, Iwanami Shoten, Tokyo, Japan, 1965. 

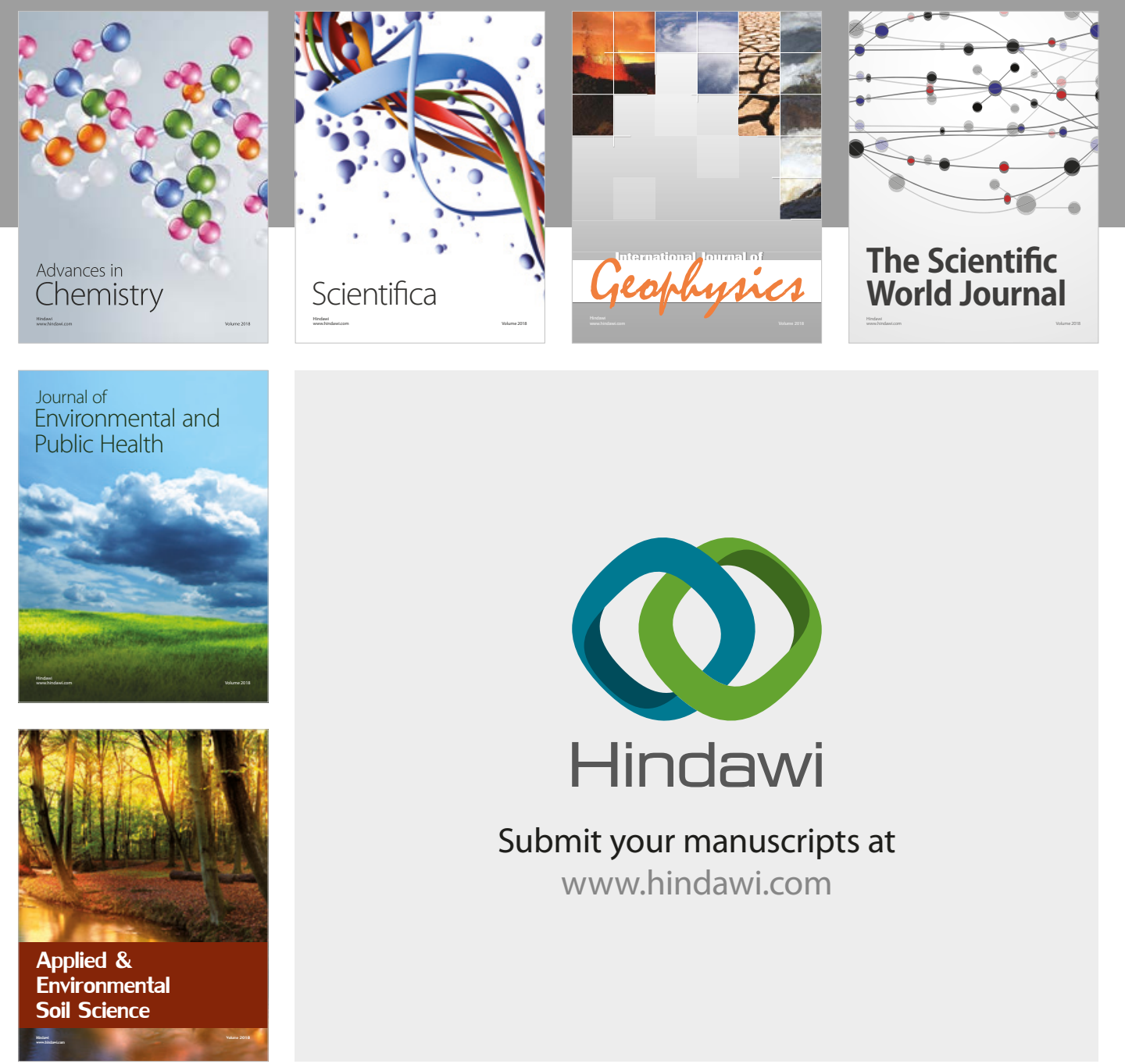

The Scientific

\section{World Journal}
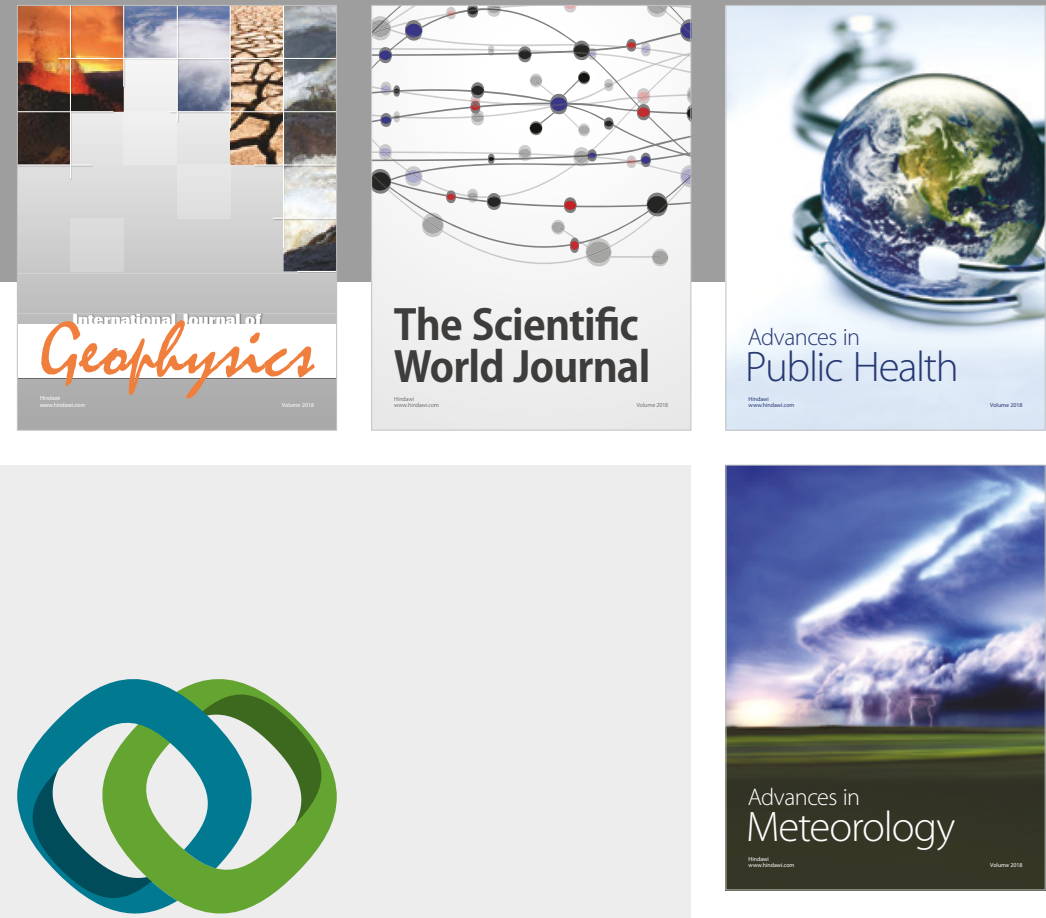

Advan

Public Health

\section{Hindawi}

Submit your manuscripts at

www.hindawi.com
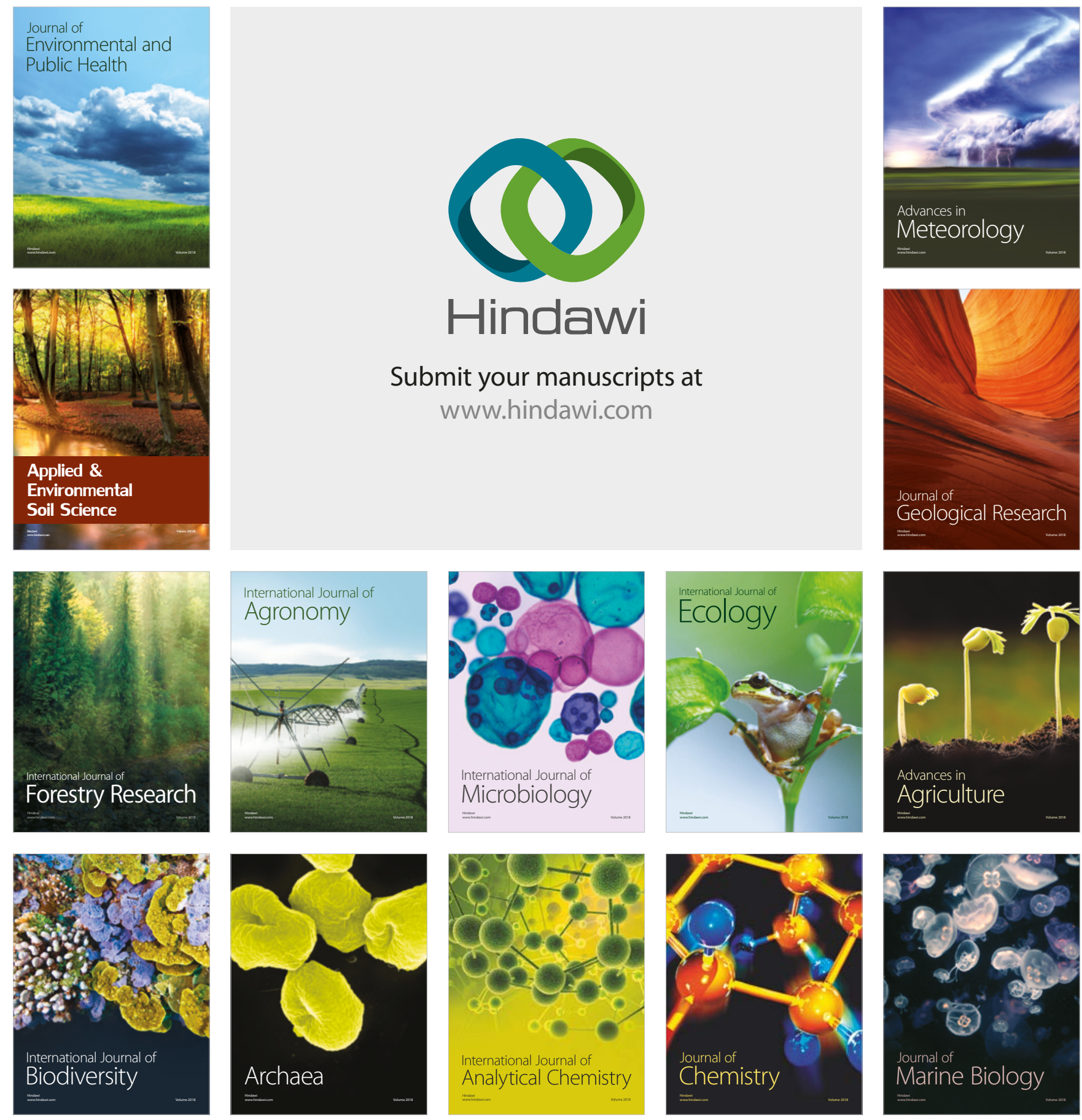